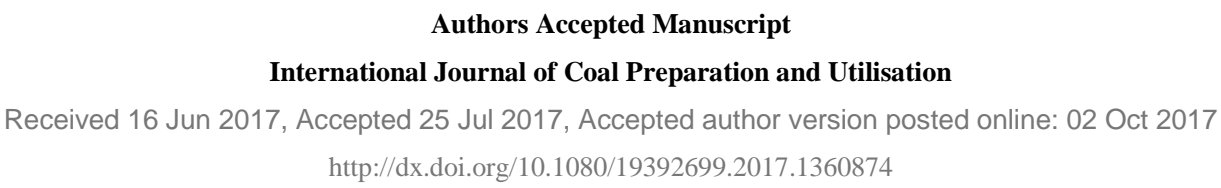

\title{
Development of a Petrographic Technique to Assess the Spontaneous Combustion Susceptibility of Indian Coals
}

\author{
${ }^{* 1,2}$ N. K. Mohalik, ${ }^{2}$ E. Lester and ${ }^{2}$ I. S. Lowndes \\ ${ }^{1}$ Senior Scientist, Mine Ventilation Division, CSIR-CIMFR, Barwa Road, Dhanbad, India \\ ${ }^{2}$ Fluids and Thermal Engineering Research Group, Faculty of Engineering, University of Nottingham, \\ Nottingham, NG7 2RD, UK \\ * Corresponding author: niroj.mohalik@ gmail.com; +91-9471192423 \\ ORCID iD: https://orcid.org/0000-0003-1521-432X
}

\begin{abstract}
Petrographic studies are commonly used categorise the potential utilisation of coals due to their simplicity, availability and low cost. Eleven coal core samples from the Jharia coalfield (JCF), India were studied using petrographic techniques (both manual and automated) to investigate maceral content, reflectance and textural characteristics. Multiple test samples of each coal were slowly oxidised under controlled laboratory conditions from an ambient temperature of $30{ }^{\circ} \mathrm{C}$ to $300{ }^{\circ} \mathrm{C}$ to investigate the morphology of oxidised coals under laboratory conditions. The petrographic characterisation of the coals before and after oxidation showed important changes in both morphology and vitrinite reflectance. The oxidation of the coal particles produced three predominant textural changes: particles with 'homogeneous change of reflectance $\left(\mathrm{HC}_{\mathrm{v}}\right)$, particles with 'oxidation rims $\left(\mathrm{OR}_{\mathrm{v}}\right)$ and particles with 'no changes were observed $\left(U_{v}\right)$ respectively. These textural characteristics were used to indicate how particles had interacted with oxygen at low temperatures during the early stages of oxidation. The morphological classification developed provides an alternative method to confirm the susceptibility of a coal to spontaneous combustion. Conventional thermal parameters such as crossing point temperature (CPT) were unable to identify the coals prone to spontaneous combustion, and neither was the change in reflectance of the coals observed pre- and post-oxidation. However, certain petrographic parameters could be combined with CPT values to provide a much more accurate measure for susceptibility to spontaneous combustion.
\end{abstract}

Keyword: Petrographic study, Spontaneous combustion, Morphology study, Oxidised coal, Image analysis, Principal component analysis and classification (PCCA), Fixed nonlinear regression models (FNRM) 


\subsection{INTRODUCTION}

Spontaneous combustion of coal is a very complex physico-chemical reaction caused by several intrinsic (density, calorific value $(\mathrm{CV})$, moisture content $(\mathrm{M})$, volatile matter (VM), fixed carbon (FC), ash (A), maceral content and rank, total iron, non-pyritic iron, total sulphur, pyritic sulphur, organic sulphur and sulphate sulphur contents of coal) and extrinsic factors (particle size, geological condition, mining methods and environmental condition). The interaction of each agent is not straightforward, but oxidation seems to be responsible for the observed compositional and structural changes. Different countries have adopted various methods to assess the propensity of coal to spontaneous combustion in the laboratory [1]. The different methods proposed by previous researchers may be catalogued under three types: a determination of the chemical constituents, oxygen avidity studies and thermal studies [2]. These test methods may be reclassified into five categories: chemical compositional studies, microscopy studies, thermal studies, oxygen avidity studies and advanced miscellaneous techniques [1, 3]. Petrographic studies identify maceral composition and vitrinite reflectance and can also be used to identify the mineral content and the textural relationships within the coal samples. Geologists conclude that counts of maceral with vitrinite rank are useful to determine the susceptibility of coals to spontaneous combustion [4-7]. The total amount of vitrinite plus liptinite influences the susceptibility of a coal to spontaneous combustion, and the risks to spontaneous combustion decrease with an increase in coalification $[5,6,8,9]$. The rate of oxidation is directly proportional to the vitrinite content, and inversely proportional to the higher the rank of coal [10-12]. The studies of Ogunsola and Mukula [13] conclude that the spontaneous combustion characteristics of Nigerian coals is coal specific and not simply rank dependent. All major macerals groups (vitrinite, liptinite and inertinite) are susceptible to weathering and oxidation with respect to time, temperature and environment settings. Among all the macerals vitrinite is the most vulnerable, whereas the inertinite and liptinite groups are more resistant to oxidation [14-18]. Both artificial oxidation and natural weathering may cause changes to the petrographic textures of coal. The changes observed in the petrographic texture of an oxidised coal may be due to the reaction temperature and chemical changes, which may be determined by a study of the changes observed in reflectance and morphology of the samples [9, 18-23]. Artificial oxidation due to heating presents as a brightening of the vitrinite particle and at the boundaries of particles (oxidation rims) whereas natural weathering processes produce dull rims [9, 16, 18-20, 22, 24-30].

The literature reveals the mechanisms of oxidation of a coal either by weathering or artificial oxidation and it is concluded that the study of the artificial oxidation of coals may provide a measure as to the propensity of these coals to spontaneous combustion. This paper outlines the experimental studies performed to provide a petrographic characterization of eleven coal samples collected from mines within the Jharia Coal Field (JCF), Northeast India, some of which are known to be prone to spontaneous combustion. These studies identify the macerals, vitrinite reflectance and morphological characteristics of fresh and artificial oxidised coals to assess the susceptibility of these coals to spontaneous combustion.

\subsection{MATERIALS AND METHODS}

\subsection{Sample Collection and Preparation}

Eleven coal samples were collected from different collieries within the JCF, Dhanbad, India using the channel and chip sampling method [31] to avoid the weathered exposed coal surface [32]. The representative samples were prepared in the laboratory and placed in air tight containers to minimise oxidation in the presence of air. The coal samples collected were from a range of ranks and were from both fiery and non-fiery classified coal seams. 
These of coal seam fire classifications are based on the historical record of fires as well as the present conditions of the coal seams. The location and geo-technical detail of all of the coal samples are detailed in Table 1 and Fig. 1. Among these eleven samples there were five samples (sample number: 1, 2, 3, 4 and 5) which have a present or recent past history of spontaneous combustion/fires, the remaining are classified as non-fiery.

Table 1 Location, geo-technical details and fire status of collected coal samples

\begin{tabular}{|c|c|c|c|c|c|c|}
\hline $\begin{array}{c}\text { Sample } \\
\text { Number }\end{array}$ & $\begin{array}{l}\text { Seam } \\
\text { Name }\end{array}$ & Colliery Name & Stratigraphic & Seam Depth (m) & $\begin{array}{c}\text { Seam Thickness } \\
(\mathbf{m})\end{array}$ & $\begin{array}{c}\text { Fire Status (Present } \\
\text { condition) }\end{array}$ \\
\hline 1 & S-14 & Chasnala & Barakar Series & 80 & 16.16 & Fires exist \\
\hline 2 & S-14 & Jitpur & Barren measure & 440 & 9.07 & Fires exist \\
\hline 3 & S-13 & Chasnala & Barakar Series & 150 & 8.23 & Fires exist \\
\hline 4 & S-16 & Jitpur & Barren Measure & 270 & 4.57 & Fires exist \\
\hline 5 & S-11 & Enna & Barakar Series & 60 & 7.31 & Fires exist \\
\hline 6 & $\mathrm{~S}-11$ & Bhalgora & Barakar Series & 95 & 5.80 & No fires \\
\hline 7 & $S-11$ & Simlabahal & Barakar Series & 230 & 7.70 & No Fires \\
\hline 8 & $\mathrm{~S}-12$ & Simlabahal & Barakar Series & 225 & 4.65 & No fires \\
\hline 9 & S-10 & Bhalgora & Barakar Series & 150 & 6.75 & No fires \\
\hline 10 & S-10 & Simlabahal & Barakar Series & 295 & 4.82 & No fires \\
\hline 11 & S-09 & Simlabahal & Barakar Series & 300 & 3.92 & No fires \\
\hline
\end{tabular}

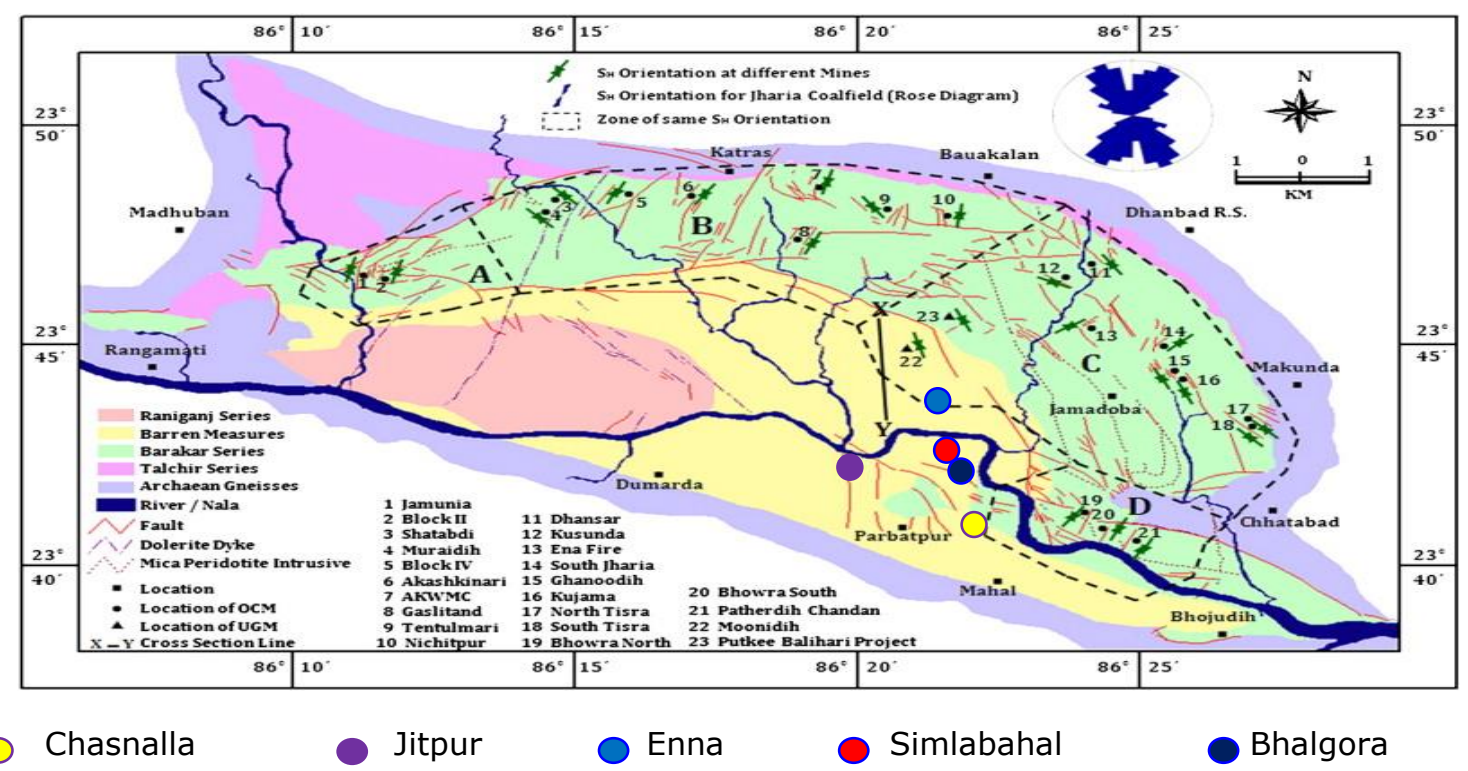

Fig. 1. Stratigraphic and in-situ stress of Jharia coalfield showing location of coal mines from where samples were collected [33]

\subsection{Coal characterization studies}

Proximate analyses including, moisture (M), ash (A), volatile matter on dry ash free (daf) basis (VM $\mathrm{VMa}_{\text {daf }}$, fixed carbon (FC); ultimate analysis (carbon $\left(\mathrm{C}_{\mathrm{daf}}\right)$, hydrogen $\left(\mathrm{H}_{\mathrm{daf}}\right)$, nitrogen $\left(\mathrm{N}_{\mathrm{daf}}\right)$, sulphur $\left(\mathrm{S}_{\mathrm{daf}}\right)$, oxygen $\left.\left(\mathrm{O}_{\mathrm{daf}}\right)\right)$; fuel ratio (FR) and gross calorific value (GCV) of all coal samples were performed to the ASTM standard. Five individual samples of each coal sample type were tested and the mean data for the repeated tests is presented in Table 2. The crossing point temperature (CPT) method is an accepted standard method for Indian coal mines to determine the susceptibility of coal to spontaneous combustion by the Directorate General Mine Safety (DGMS) [34]. In short, the higher the crossing point temperature, the lower the susceptibility of the coal to spontaneous combustion. A spontaneous combustion test rig developed at the University of Nottingham (UoN) is used to determine the crossing point temperature $\left(\mathrm{CPT}_{\mathrm{u}}\right)$ of the coal samples [9]. The results of the proximate analyses, crossing point temperatures and ignition point temperature (IPT) for each coal sample are summarised in Table 2. 
Table 2 Proximate, ultimate, GCV, FR, CPT, IPT and CPT analysis of the eleven coal samples.

\begin{tabular}{|c|c|c|c|c|c|c|c|c|c|c|c|c|c|c|}
\hline Sample & $\begin{array}{c}\text { Moisture } \\
(\% \mathrm{wt})\end{array}$ & $\begin{array}{c}\text { Ash } \\
(\% \mathrm{wt})\end{array}$ & $\begin{array}{c}\text { Volatile } \\
\text { Matter } \\
(\% \text { wt dafb })\end{array}$ & $\begin{array}{c}\text { Fixed } \\
\text { Carbon } \\
(\% \text { wt dafb })\end{array}$ & $\begin{array}{c}\mathbf{C} \\
(\% \mathrm{wt} \\
\text { dafb })\end{array}$ & $\begin{array}{c}\mathbf{H} \\
(\% \mathrm{wt} \\
\text { dafb })\end{array}$ & $\begin{array}{c}\mathbf{N} \\
(\% w t \\
\text { dafb })\end{array}$ & $\begin{array}{c}\mathbf{S} \\
(\% \mathrm{wt} \\
\text { dafb })\end{array}$ & $\begin{array}{c}\mathbf{O} \\
(\% \mathrm{wt} \\
\text { dafb })\end{array}$ & $\begin{array}{c}\text { Calorific } \\
\text { Value } \\
\text { (MJ/kg) }\end{array}$ & $\begin{array}{c}\text { Fuel } \\
\text { Ratio }\end{array}$ & $\begin{array}{c}\text { Crossing } \\
\text { Point } \\
\text { Temperature } \\
\left({ }^{\circ} \mathrm{C}\right)\end{array}$ & $\begin{array}{c}\text { Ignition } \\
\text { Point } \\
\text { Temperature } \\
\left({ }^{\circ} \mathrm{C}\right)\end{array}$ & $\begin{array}{c}\text { Crossing } \\
\text { Point } \\
\text { Temperature } \\
\text { (Nottingham) } \\
\text { CPT }_{\mathbf{u}}\left({ }^{\circ} \mathrm{C}\right)\end{array}$ \\
\hline 1 & 1.14 & 10.31 & 30.69 & 61.37 & 77.16 & 4.92 & 1.52 & 0.28 & 16.10 & 29.64 & 2.26 & 145 & 164 & 213 \\
\hline 2 & 1.18 & 10.84 & 29.54 & 61.99 & 79.77 & 4.81 & 1.58 & 0.27 & 13.57 & 28.86 & 2.38 & 142 & 173 & 206 \\
\hline 3 & 1.16 & 7.78 & 32.44 & 61.52 & 79.85 & 5.28 & 1.57 & 0.31 & 12.98 & 29.29 & 2.08 & 136 & 157 & 196 \\
\hline 4 & 1.30 & 9.34 & 30.06 & 62.50 & 79.12 & 4.91 & 1.43 & 0.32 & 14.21 & 28.68 & 2.33 & 152 & 186 & 211 \\
\hline 5 & 0.61 & 20.94 & 26.95 & 57.31 & 81.31 & 5.02 & 1.62 & 0.00 & 12.06 & 25.59 & 2.71 & 169 & 199 & 231 \\
\hline 6 & 1.22 & 16.71 & 28.26 & 58.88 & 83.96 & 5.06 & 1.88 & 0.54 & 8.57 & 27.42 & 2.54 & 171 & 199 & 228 \\
\hline 7 & 1.25 & 13.40 & 27.22 & 62.11 & 82.10 & 4.69 & 1.73 & 0.41 & 11.07 & 28.34 & 2.67 & 159 & 185 & 218 \\
\hline 8 & 1.13 & 16.74 & 26.42 & 60.44 & 79.99 & 4.81 & 1.64 & 0.50 & 13.05 & 27.24 & 2.79 & 152 & 176 & 211 \\
\hline 9 & 0.64 & 17.19 & 24.86 & 61.74 & 83.94 & 4.73 & 1.90 & 0.35 & 9.08 & 26.72 & 3.02 & 165 & 198 & 216 \\
\hline 10 & 0.63 & 16.75 & 25.08 & 61.90 & 84.14 & 4.95 & 1.90 & 0.39 & 8.63 & 27.46 & 2.99 & 168 & 197 & 222 \\
\hline 11 & 0.92 & 16.88 & 27.02 & 59.99 & 83.53 & 4.94 & 2.00 & 0.50 & 9.04 & 26.77 & 2.70 & 162 & 188 & 223 \\
\hline
\end{tabular}




\subsection{Petrographic studies of fresh coals}

The determination of the maceral contents and rank of a coal sample requires the preparation and analysis of representative blocks for each coal sample. Polished blocks of each of the coal samples were prepared [1,35], and manually examined using a Leitz Ortholux II POL-BK microscope to perform maceral [36] and rank analysis [37] of the blocks. Subsequently, the whole coal reflectance was measured using image analysis technique with an automatic stage controller on the microscope, using 8 bit black and white imaging Zeiss AxioCam. The camera images were calibrated using a sapphire standard with a reflectance value of $0.58 \%$. Four mosaic images of 100 frames each (total of 12,012,000 pixels from 10x10 individual images) were captured across each coal block and averaged to give an accurate value for each coal sample [9, 38-40]. Fig. 2 shows an example of these mosaics. The results of the maceral and rank analysis conducted for all of the eleven coal samples using manual microscopic method, automated image analysis are summarised in Table 3.

Manually derived data has been split into the main macerals but dividing the inertinite maceral into semi-fusinite and fusinite - representing the main inertinite sub-macerals. The manual data has the suffix $\mathrm{m}_{\mathrm{m}}$ is then presented as $\mathrm{VL}_{\mathrm{m}}, \mathrm{SF}_{\mathrm{m}} \mathrm{F}_{\mathrm{m}}$, and $\mathrm{VR}_{\mathrm{m}}$ which means the vitrinite and liptinite (the most reactive fractions), semi-fusinite, fusinite and vitrinite reflectance, respectively. The automated image analysis data has the suffix ${ }_{i}$ and is presented as $\mathrm{VL}_{\mathrm{i}}$, $\mathrm{SF}_{\mathrm{i}}, \mathrm{F}_{\mathrm{i}}$ and $\mathrm{VR}_{\mathrm{i}}$. It should be noted that the $\mathrm{VR}_{\mathrm{i}}$ data does not correspond directly to the $\mathrm{VR}_{\mathrm{o}}$ because it does not sample vitrinite in the same way as the manual ISO standard which specifically measures the most homogeneous desmocollinite (normally) and away from any edges. With VRi, the calculation is based on the average reflectance value was calculated from the main grey scale histogram peak using Equation 1:

$$
\mathrm{R}_{\mathrm{avg}}(\%)=\sum_{\mathrm{i}=\mathrm{m} 1}^{\mathrm{i}=\mathrm{m} 2} \frac{\mathrm{R}_{\mathrm{i}} \times \mathrm{Pix}_{\mathrm{i}}(\%)}{\operatorname{Pix}_{\mathrm{i}}(\%)}
$$

Where $\mathrm{i}$ - the grey scale value; $\mathrm{m} 1$ - minima prior to peak maxima; $\mathrm{m} 2$ - minima post main peak; $\mathrm{R}$ - Correspondent reflectance value; Pix (\%) - Pixel percentage value associated; N- Number of grey scale value used. As such, the automated program is not specifically only measuring the best vitrinite and can also have some semi-fusinite and some liptinite, where reflectance profiles (between macerals) overlap. There are also edge effects that introduce wider reflectance range. However this parameter is still worth using as it is a relative measure, contains $10^{6} \mathrm{x}$ more measurements than manual vitrinite reflectance and $\mathrm{VR}_{\mathrm{i}}$ can be compared easily with the $\mathrm{VR}_{\mathrm{i}}$ from each treated sample directly.

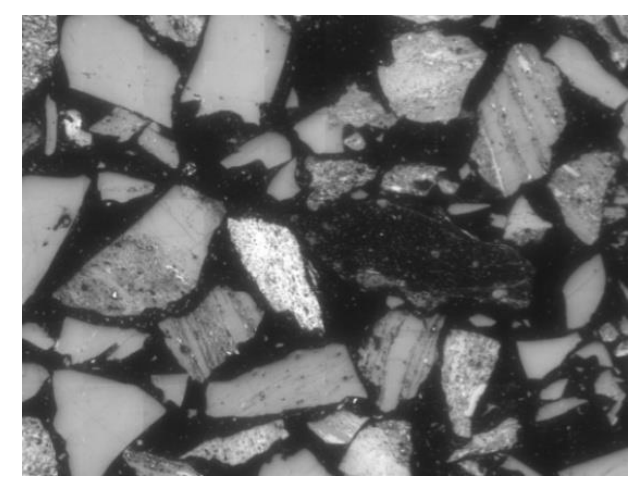

Fig. 2. An example mosaic image for image analysis 
Table 3. Petrographic analyses (maceral and rank) of coal samples using the manual and image analysis techniques.

\begin{tabular}{|c|c|c|c|c|c|c|c|c|c|c|}
\hline \multirow[b]{2}{*}{$\begin{array}{l}\text { Sample } \\
\text { Number }\end{array}$} & \multicolumn{6}{|c|}{ Manual Analysis } & \multicolumn{4}{|c|}{ Automated Analysis } \\
\hline & $\begin{array}{l}\text { Vitrinite } \\
\text { (Vm) }\end{array}$ & $\begin{array}{c}\text { Liptinite } \\
\text { (Lm) }\end{array}$ & $\begin{array}{l}\text { Semi-Fusinite } \\
\text { (SFm) }\end{array}$ & $\begin{array}{c}\text { Fusini } \\
\text { te } \\
(\mathrm{Fm})\end{array}$ & $\begin{array}{l}\text { Vitrinite+Lipt } \\
\text { inite }(\mathrm{VLm})\end{array}$ & $\begin{array}{c}\text { Vitrinite } \\
\text { Reflectance } \\
(\mathrm{VRm})\end{array}$ & $\begin{array}{c}\text { Vitrinite+Liptinite } \\
\text { (VLi) }\end{array}$ & $\begin{array}{l}\text { Semi-Fusinite } \\
\text { (SFi) }\end{array}$ & $\begin{array}{l}\text { Fusinite } \\
\text { (Fi) }\end{array}$ & $\begin{array}{c}\text { Peak } \\
\text { Reflectance } \\
\text { (VRi) }\end{array}$ \\
\hline 1 & 67.2 & 2.4 & 21.6 & 3.6 & 74.8 & 0.74 & 74.0 & 22.9 & 3.2 & 0.66 \\
\hline 2 & 69.2 & 1.6 & 18.8 & 3.6 & 77.6 & 0.76 & 78.5 & 19.7 & 4.3 & 0.66 \\
\hline 3 & 62.4 & 1.6 & 10.4 & 9.2 & 80.4 & 0.87 & 79.9 & 10.9 & 9.2 & 0.68 \\
\hline 4 & 72.0 & 2.8 & 23.6 & 6.8 & 69.6 & 0.97 & 71.5 & 21.4 & 7.1 & 0.67 \\
\hline 5 & 40.4 & 0.8 & 27.2 & 6.0 & 66.8 & 1.00 & 66.1 & 26.9 & 1.0 & 0.77 \\
\hline 6 & 74.4 & 3.2 & 26.4 & 4.0 & 69.6 & 1.02 & 72.8 & 22.9 & 4.3 & 0.91 \\
\hline 7 & 55.2 & 1.2 & 27.2 & 8.8 & 64.0 & 1.15 & 65.7 & 18.1 & 16.3 & 0.90 \\
\hline 8 & 74.8 & 5.6 & 36.0 & 7.6 & 56.4 & 1.08 & 58.0 & 37.8 & 4.3 & 0.80 \\
\hline 9 & 68.4 & 1.2 & 46.0 & 12.8 & 41.2 & 1.04 & 41.4 & 45.5 & 13.1 & 0.94 \\
\hline 10 & 57.2 & 1.2 & 32.0 & 9.6 & 58.4 & 1.05 & 60.0 & 21.7 & 18.3 & 1.00 \\
\hline 11 & 64.8 & 2.0 & 25.2 & 4.0 & 70.8 & 1.09 & 73.2 & 24.2 & 2.6 & 0.77 \\
\hline
\end{tabular}




\subsection{Petrographic studies of oxidised coals}

Previous investigations have studied the changes in the vitrinite reflectance and morphology of coal samples heated in the laboratory. These methods have number of inherent limitations: all samples may not be uniformly heated in the sample holder and small particle sizes may produce cracks and binding problems. Given these challenges, an alternative method was explored to study thermally treated coal samples. Freshly prepared coal samples (amount: $10 \mathrm{gm}$, size: +425 micron to $-1 \mathrm{~mm}$ ) were placed in a crucible and heated at $3{ }^{\circ} \mathrm{Cmin}^{-1}$ in a muffle furnace up to a maximum temperature of $300^{\circ} \mathrm{C}$ and held for a further 30 minutes $\left(200{ }^{\circ} \mathrm{C}\right.$ and $250{ }^{\circ} \mathrm{C}$ were tested but did not create any change in reflectance and morphology). Repeatability of experimental results was verified with all coal samples by carrying out five experiments on each coal sample. Manual vitrinite reflectance measurements were taken at the centre of any vitrinite particles, to avoid the subjective influence of any oxidation rims surrounding the particle that exhibit no change in reflectance due to heating. Similarly morphology studies of the two morphotypes of vitrinite were considered i.e. unaltered material $\left(U_{v}\right)$ and altered material $\left(A_{v}\right)$. The altered material may be grouped into two classes i.e. the homogenous changes of reflectance (across the whole particle either bright or dull) and the oxidation rims (with homogenous change or not, oxidation rim with cracks, micro fractures and internal oxidation lines). Changes in the vitrinite morphology was manually determined using and identified the presence of the three morphotype groups - unaltered vitrinite $\left(U_{v}\right)$, homogenous change of vitrinite $\left(\mathrm{HC}_{\mathrm{v}}\right)$ and vitrinite having oxidation rims $\left(\mathrm{OR}_{\mathrm{v}}\right)$. The mosaic images and their corresponding vitrinite sub-classifications $\mathrm{U}_{\mathrm{v}}, \mathrm{HC}_{\mathrm{v}}$ and $\mathrm{OR}_{\mathrm{v}}$ are shown in Figs. 3a-c. The vitrinite reflectance measurements were performed on the sample blocks using the automated image analysis techniques. The vitrinite reflectance and morphological results obtained from the oxidised (thermally altered) coals for both manual and image analysis techniques are given in Table 4. Examples of a comparison of the analysis of the fresh and oxidised samples using cumulative average techniques for image analysis is shown in Figs. 4a-b. Figs. 4a,b \&e clearly indicate the vitrinite levels of the oxidised sample are very high which means the reflectance values increase after oxidation. But an analysis of Figs. 4c,d\&f reveals that the reflectance of the oxidised coal is lower than the corresponding untreated samples. The observed changes in the reflectance results for both manual and image analysis techniques are given in Fig. 5. 


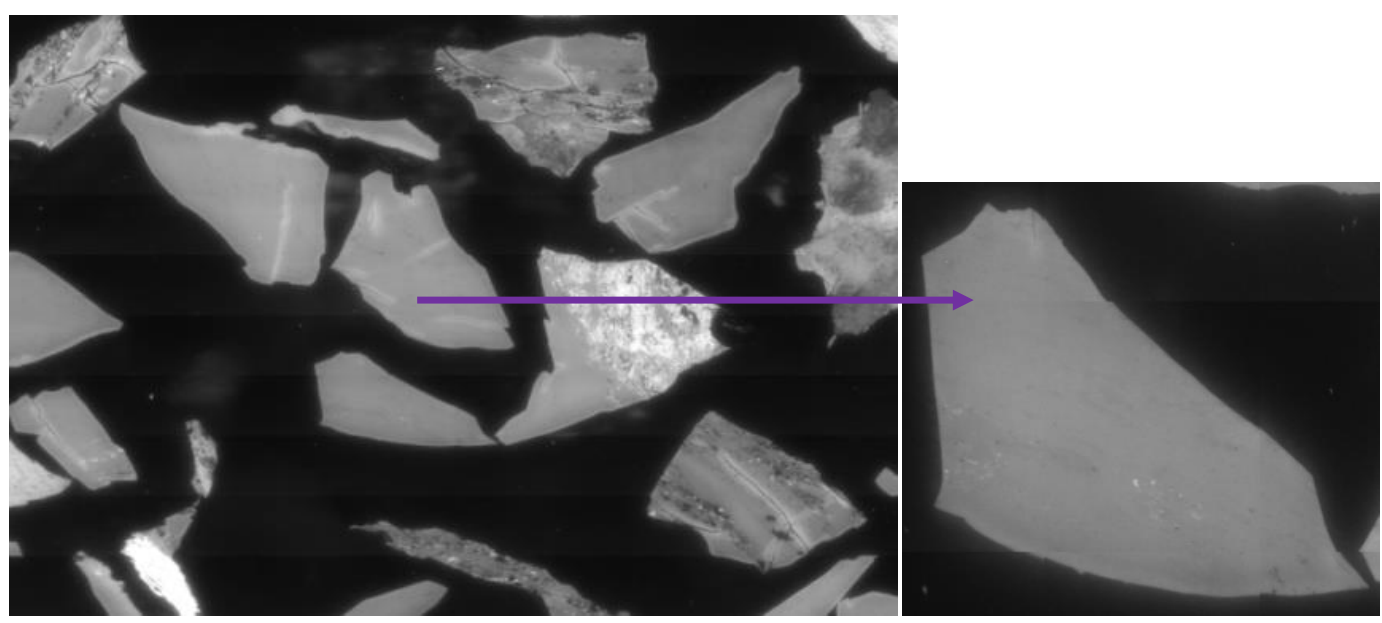

Fig. 3 (a) Mosaic images heated coal samples using muffle furnace (b) Unaltered vitrinite

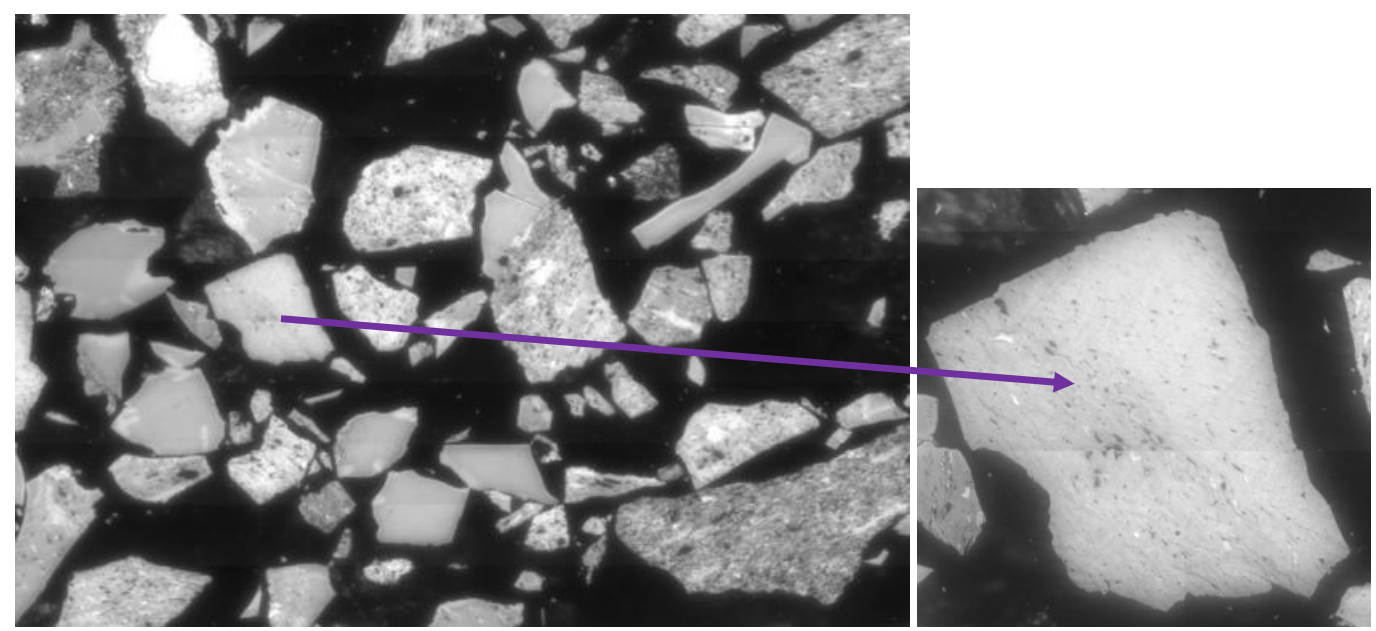

Fig. 3 (b) Mosaic images heated coal samples using muffle furnace (b) Homogenous change vitrinite

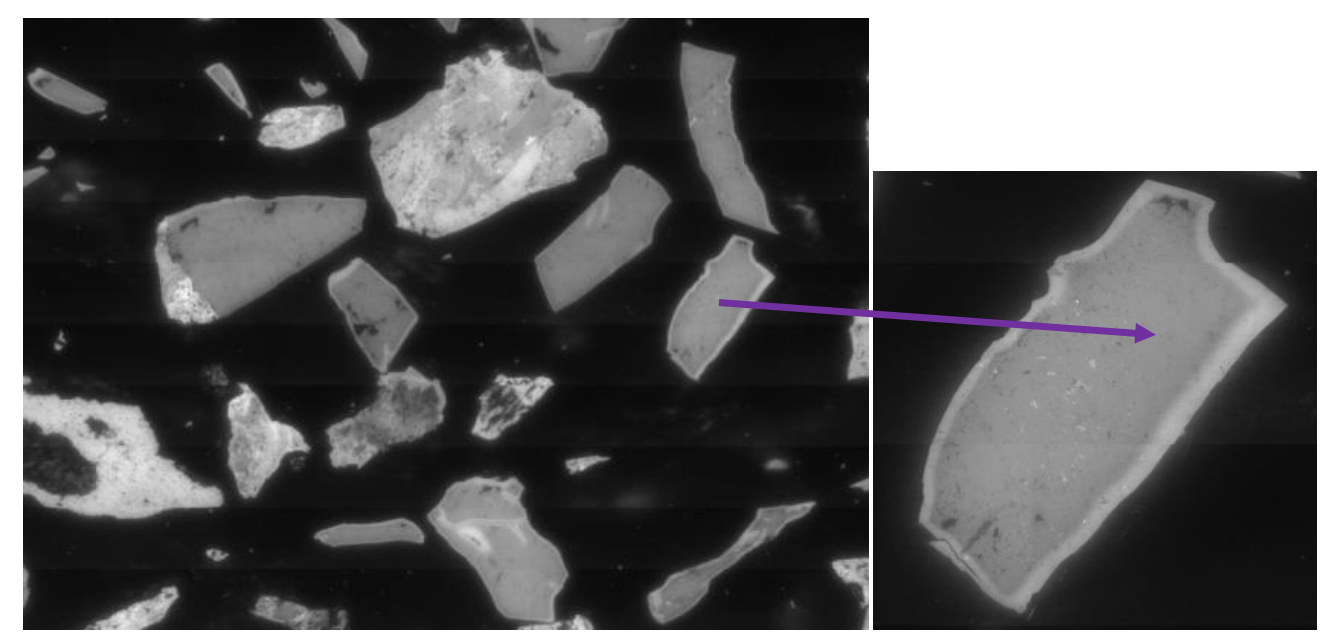

Fig. 3 (c) Mosaic images coal samples heated using muffle furnace (b) Vitrinite having oxidation rim 
Table 4 Petrographic analyses (morphology and rank) of oxidized coal obtained using a manual and image analysis technique.

\begin{tabular}{|c|c|c|c|c|c|c|c|}
\cline { 2 - 8 } \multicolumn{1}{c|}{} & \multicolumn{5}{c|}{ Manual Analysis } & \multicolumn{2}{c|}{ Automated Analysis } \\
\hline Sample & $\mathbf{U}_{\mathbf{v}}$ & $\mathbf{H C}_{\mathbf{v}}$ & $\mathbf{O R}_{\mathbf{v}}$ & $\mathbf{V R}_{\mathbf{m o}}$ & $\mathbf{V R}_{\mathbf{m o}-\mathbf{m}}$ & VR $_{\mathbf{i o}}$ & VR $_{\text {io-i }}$ \\
\hline 1 & 10.0 & 10.4 & 79.6 & 1.05 & 0.31 & 0.76 & 0.23 \\
\hline 2 & 15.2 & 10.0 & 74.8 & 0.92 & 0.16 & 1.01 & 0.35 \\
\hline 3 & 4.8 & 5.2 & 90.0 & 0.91 & 0.04 & 0.74 & 0.24 \\
\hline 4 & 23.0 & 20.4 & 53.6 & 1.04 & 0.07 & 0.87 & 0.2 \\
\hline 5 & 27.2 & 6.4 & 66.4 & 1.02 & 0.02 & 0.91 & 0.14 \\
\hline 6 & 17.2 & 10.4 & 72.4 & 1.04 & 0.02 & 0.96 & 0.05 \\
\hline 7 & 33.6 & 9.2 & 57.2 & 1.02 & -0.13 & 0.84 & -0.06 \\
\hline 8 & 26.8 & 12.8 & 60.4 & 0.95 & -0.13 & 0.71 & -0.09 \\
\hline 9 & 49.6 & 16.0 & 34.4 & 1.03 & -0.01 & 0.68 & -0.2 \\
\hline 10 & 48.0 & 5.6 & 46.4 & 1.08 & 0.03 & 1.04 & 0.04 \\
\hline 11 & 26.0 & 10.0 & 64.0 & 1.1 & 0.01 & 0.8 & 0.03 \\
\hline
\end{tabular}

$U_{v}$ - Unaltered vitrinite, (\%); $H C_{v}-H o m o g e n o u s$ change vitrinite, (\%); OR $R_{v}$ Oxidation rim vitrinite (\%); $V R_{m o}$ - vitrinite reflectance of oxidised coal manual,; $V R_{m o-m}$ difference between vitrinite reflectance of oxidised and fresh coal; $V R_{i o}$ - vitrinite reflectance image analysis of oxidised coal,; $V R_{i o-i}$ difference between vitrinite reflectance image analysis oxidised and fresh coal.

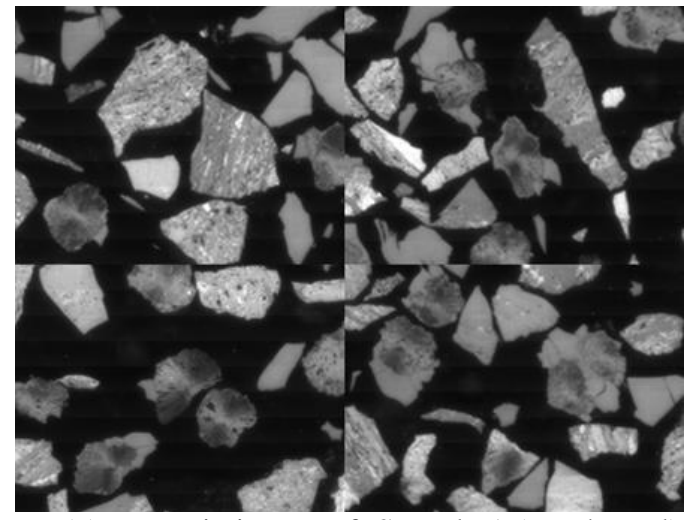

(a) Mosaic image of Sample 1 (Fresh coal)

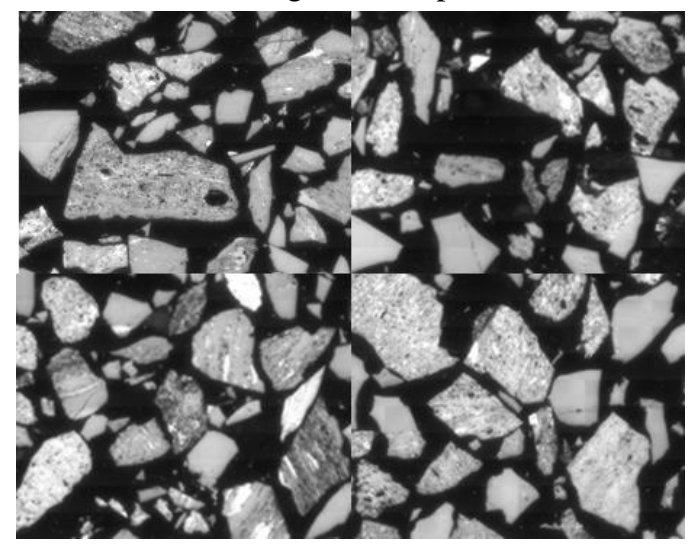

(c) Mosaic image of Sample 9 (Fresh coal)

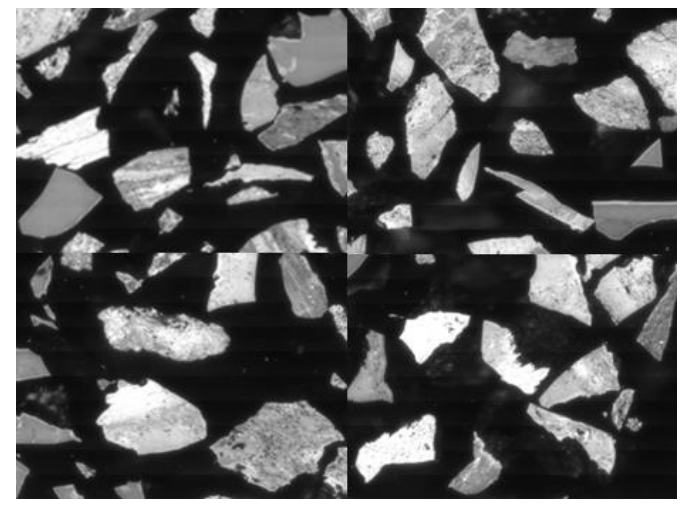

(b) Mosaic image of Sample 1 (Oxidised coal)

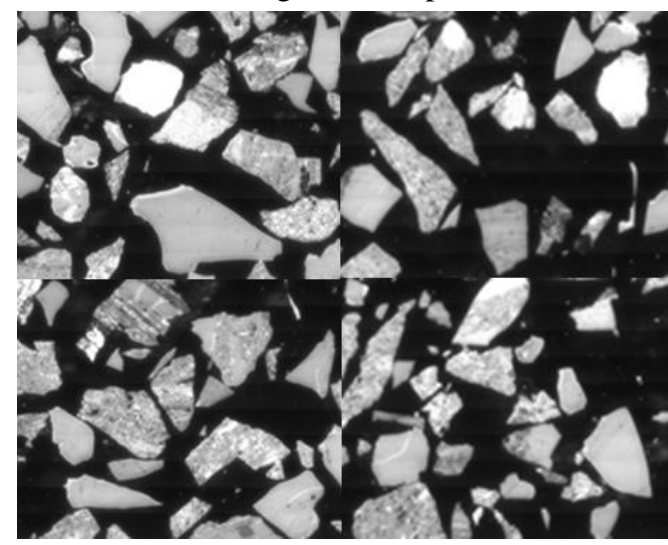

(d) Mosaic image of Sample 9 (Oxidised coal) 


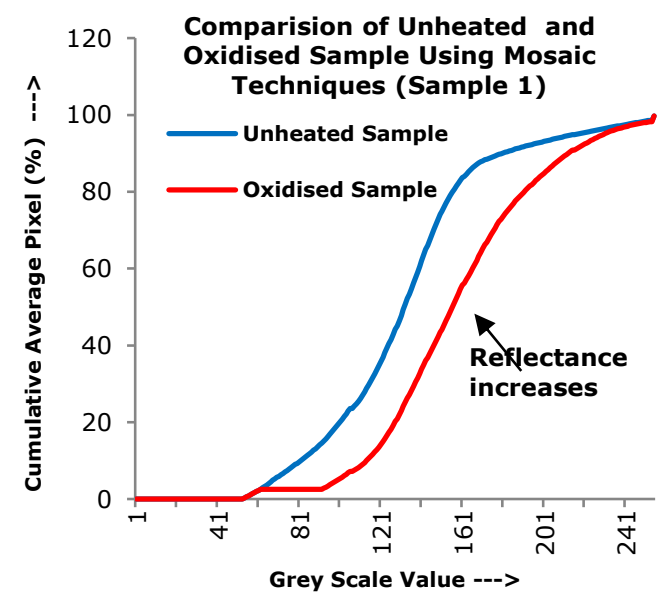

(e) Sample 1 (higher reflectance)

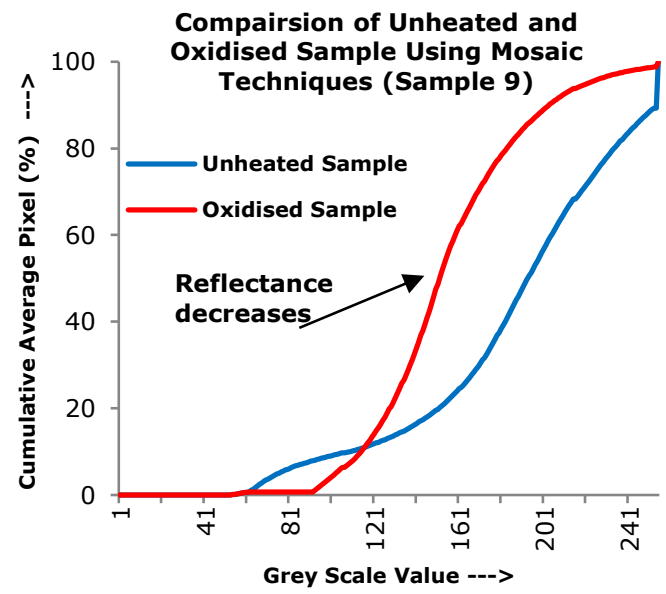

(f) Sample 9 (lower reflectance)

Fig. 4. Reflectance study of fresh and oxidised coal samples (mosaic techniques)

\subsection{ANALYSIS OF RESULTS}

\subsection{Basic coal characterization}

The proximate analyses of coal samples $1 \& 2$ (same seam, different depth and stratigraphic stages) are similar in nature even though the difference in depth is very high at $360 \mathrm{~m}$. In the case of samples 5, 6, and 7 (same seam, stratigraphic stages and different depth) the percentage of FC and $\mathrm{VM}_{\text {daf }}$ increases with depth, whereas the ash and moisture decreases with depth. Similarly, samples $9 \& 10$ (same seam, stratigraphic stages and different depth) are similar in nature even though the difference in depth is relatively high. The ultimate analysis results for samples 1 and 2 shows that the percentage of $\mathrm{C}_{\mathrm{daf}}$ and $\mathrm{N}_{\mathrm{daf}}$ increases as per depth and the percentage of $\mathrm{H}_{\mathrm{daf}}, \mathrm{S}_{\mathrm{daf}}, \mathrm{O}_{\mathrm{daf}}$ decreases as per depth and stratigraphic stages. The percentage of $C_{d a f}$ increases for sample number 5, 6 and 7 as depth increases whereas percentage of $\mathrm{H}_{\mathrm{daf}}, \mathrm{S}_{\mathrm{daf}}, \mathrm{N}_{\mathrm{daf}}$ and $\mathrm{O}_{\mathrm{daf}}$ are similar except sample 6. The composition of $\mathrm{C}_{\mathrm{daf}}, \mathrm{H}_{\mathrm{daf}}, \mathrm{N}_{\mathrm{daf}}$ and $\mathrm{S}_{\mathrm{daf}}$ slightly increases or are similar in nature as depth increases whereas oxygen content decreases with depth. The CPTs vary across a range from $136{ }^{\circ} \mathrm{C}$ with sample 3 , to $171{ }^{0} \mathrm{C}$ with sample 6 . The CPT values determined for samples 3 is low $\left(<140{ }^{\circ} \mathrm{C}\right)$ which is categorised as highly prone to spontaneous combustion, whereas sample number $1,2,4,7$ and 8 are in the range of 140 to $160{ }^{\circ} \mathrm{C}$ which are moderately susceptible and sample number 5, 6, 9, 10 and 11 are high $\left(>160^{\circ} \mathrm{C}\right)$, which denotes low susceptibility to spontaneous combustion. The determined IPTs vary across a range from $157{ }^{\circ} \mathrm{C}$ (sample 3 ) to $171{ }^{0} \mathrm{C}$ (sample 5 and 6). The $\mathrm{CPT}_{\mathrm{u}}$ values vary across a range from between $196{ }^{\circ} \mathrm{C}$ (sample 8) to $231^{\circ} \mathrm{C}$ (sample 5).

\subsection{Petrographic studies of fresh and oxidised coal}

The vitrinite and liptinite percentages $\left(\mathrm{VL}_{\mathrm{m}}\right)$ show a broad range between $41 \%$ - $80 \%$. Semifusinite $\left(\mathrm{SF}_{\mathrm{m}}\right)$ also shows a broad range from $10-46 \%$. Fusinite levels $\left(\mathrm{F}_{\mathrm{m}}\right)$ show a more modest range from $3.6-12.8 \%$. There were no significant pyrite content levels detected in the coal samples which removes the possibility of self-heating through pyrite based mechanisms[41, 42]. Automated analysis data shows similar ranges. Fresh samples show a $\mathrm{VR}_{\mathrm{m}}$ from $0.74-1.15 \%$. The vitrinite content increases as depth increase for samples 1 and 2 and sample 9 and 10 except sample number 5, 6 and 7. Similarly the rank of coal sample increases as depth increases for all samples. The VRi range is slightly lower for reasons discussed in Section 2.3. 
With the oxidised samples, the unaltered vitrinite $\left(\mathrm{U}_{\mathrm{v}}\right)$ percentage varies from $4.8 \%$ (sample 3, Table 4 ) to $49.6 \%$ (sample 9: Table 4). The homogenous change vitrinite $\left(\mathrm{HC}_{\mathrm{v}}\right)$ percentage varies from 5.2 (sample 3 ) to $20.4 \%$ (sample 4) whereas oxidation rim vitrinite $\left(\mathrm{OR}_{\mathrm{v}}\right)$ percentage varies from 90.0 (sample 3 ) to $34.4 \%$ (sample 9) respectively. The oxidation rims around the vitrinite are due to heat exchange between coal and oxygen available at the surface. Samples 1, 2 and 3 are the most reactive as most of the vitrinite is altered (> $70 \%$ with $\mathrm{HC}_{\mathrm{v}}+\mathrm{OR}_{\mathrm{v}}$ ) and the recorded morphological changes make a significant contribution to the classification of these coals as to their susceptibility to spontaneous heating.

Fig. 5 plots the relative change in vitrinite reflectance from fresh to oxidised $\left(\mathrm{VR}_{\mathrm{m} 0}-\mathrm{VR}_{\mathrm{m}} / \mathrm{VR}_{\mathrm{m}}\right)$ varies from $0.91 \%$ (sample 3) to $1.10 \%$ (sample 11). $\mathrm{VR}_{\mathrm{m}}$ and $\mathrm{VR}_{\mathrm{i}}$ of samples 1, 2, 3, 4 and 5 increases significantly which means these coals are the most responsive to change during oxidation. Samples 6, 10 and 11 only show a modest increase in reflectance and coal samples 7,8 and 9 appear to show a modest decrease. Previous studies have suggested that the vitrinite reflectance of samples undergoing artificial oxidation increases[43-45]. Oxidation of coal under laboratory conditions may also produce a dull appearance[43, 44, 46-48]. The reason behind the observed reduction in reflectance is not fully understood and needs further study using a large number of samples.

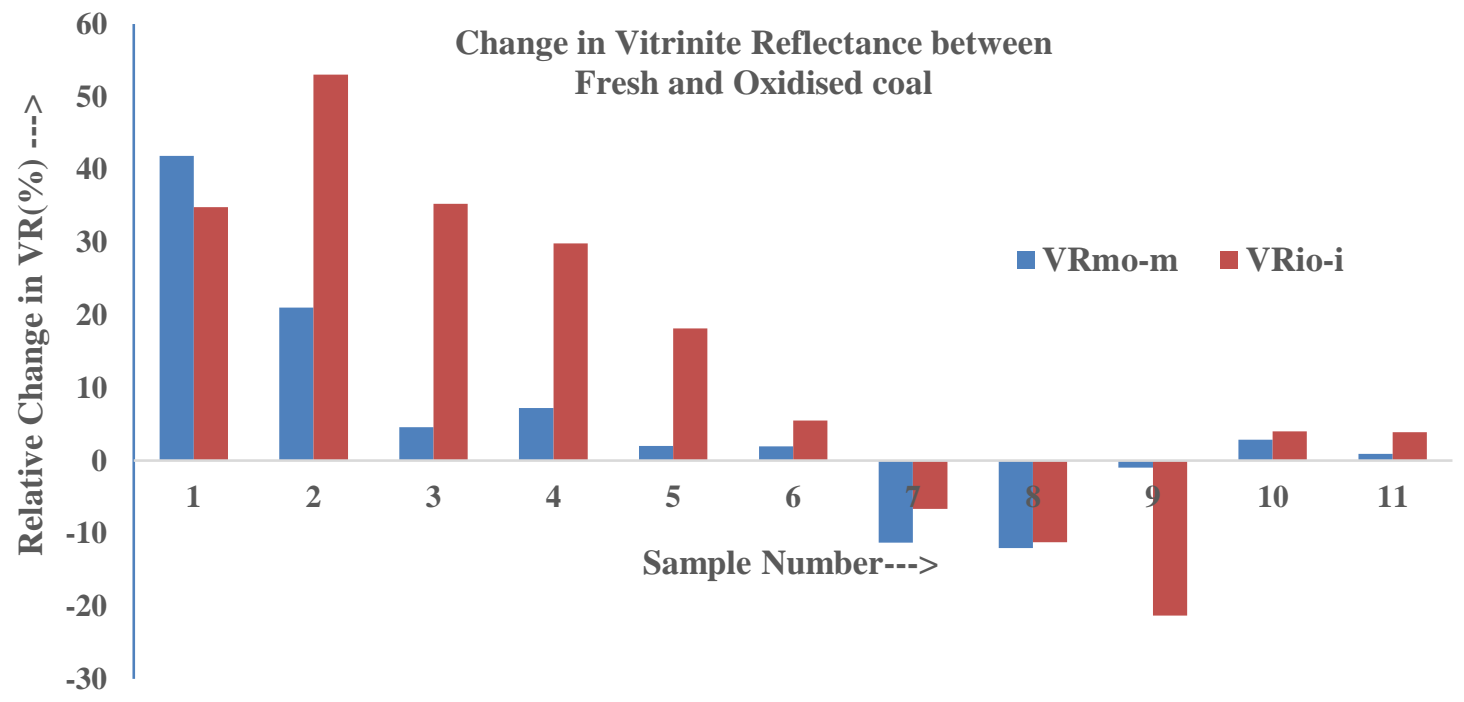

Fig. 5. Change in reflectance recorded for fresh and oxidised coal samples

\subsection{Chemo-metric Analysis}

\subsubsection{Correlation Analysis}

The proximate and petrographic data obtained from the above studies were subsequently statistically compared using correlation analysis, multivariate analysis (i.e. principal component and classification analysis (PCCA) and fixed nonlinear regression models (FNRM)). The Statistica 7.1 statistical package was used [49, 50] to preform correlation studies to identify potential relationships between the different spontaneous combustion susceptibility indices $\left(\mathrm{CPT}, \mathrm{CPT}_{\mathrm{u}}, \mathrm{U}_{\mathrm{v}}, \mathrm{HC}_{\mathrm{v}}(\%), \mathrm{OR}_{\mathrm{v}}(\%), \mathrm{VR}_{\mathrm{mo}-\mathrm{m}}, \mathrm{VR}_{\mathrm{io}-\mathrm{i}}\right)$ and the coal characteristic data provided by the proximate, ultimate, GCV, FR; and petrographic analyses of coal samples. The values of the correlation 
coefficients determined ( $\mathrm{p}<0.05$ confidence interval) for the above studies are presented in Table 5 and 6 . It reveals that there is a stronger correlation between the oxidised coal properties and the chemical constituents of the coals than for any of the other parameters. A study of the data presented on Table 5 and 6 reveals that CPT and CPTu, possesses the highest significance with the ash content $(r=0.858, r=0.833), \mathrm{U}_{\mathrm{v}}$ correlates well to $\mathrm{VM}_{\text {daf }}(\mathrm{r}=0.912)$ and $\mathrm{VR}_{\mathrm{io}-\mathrm{i}}$ with $\mathrm{VL}_{\mathrm{m}}(\mathrm{r}=0.858)$. The positive correlation coefficients reveals it has positive correlation, whereas negative correlation indicates a weak relationship.

\subsubsection{Principal component and classification analysis (PCCA)}

The PCCA technique is widely applied to analyse highly complex datasets. The method seeks to reduce the dimensionality of the data set and to identify relationships between variables. An application of these methods to the results of the coal analyses described above, concludes that there is low correlation between the results of the ultimate analysis e.g. nitrogen and low sulfur content $(<0.54 \%)$ with the tendency of a coal to spontaneously combust. Similarly, from the petrographic analyses, it is concluded that the recorded semifusinite $\left(\mathrm{SF}_{\mathrm{m}}, \mathrm{SF}_{\mathrm{i}}\right)$ and fusinite $\left(\mathrm{F}_{\mathrm{m}}, \mathrm{F}_{\mathrm{i}}\right)$ levels do not influence the propensity of a coal to spontaneously combustion of coal[44, 46, 47]. The Statistica 7.1 computer package was used to perform the PCCA studies. The PCCA analyses performed considered the relationships between the following eleven determined coal characteristic variables (moisture M, ash A, volatile matter $\mathrm{VM}_{\mathrm{daf}}$, fixed carbon $\mathrm{FC}$, carbon $\mathrm{C}_{\mathrm{daf}}$, hydrogen $\mathrm{H}_{\mathrm{daf}}$, oxygen $\mathrm{O}_{\mathrm{daf}}$, calorific value $\mathrm{GCV}$, fuel ratio $F R$, vitrinite + liptinite $\mathrm{VL}_{\mathrm{m}}$, vitrinite reflectance $\mathrm{VR}_{\mathrm{m}}$ ), with the four susceptibility indices determined for each coal sample $\left(\mathrm{CPT}, \mathrm{CPT}_{\mathrm{u}}, \mathrm{U}_{\mathrm{v}}\right.$ and $\left.\mathrm{VR}_{\mathrm{io}-\mathrm{i}}\right)$. For this study the principal components (PCs) with Eigen values greater than 1.0 were considered. However, the total variance for the given data sets, is observed to vary by up to $88 \%$ for the first three PCs, and found very small values for the remaining eight PCs (Table 7). The eigenvalues of these three PCs, modify the magnitude of the corresponding eigenvectors significantly (Table 8). The eigenvectors with the largest eigenvalues identify the parameters with the strongest correlation in the data set. Similarly, the scree plot finds the factorial loadings where the observed decrease in eigenvalues appears to level off to the right of the plot. As a result the first three PCs were selected for the principal component matrix. The factorial loadings and their projections of variable on the factor plane (1x2) are depicted in Table 8 and Fig. 6. Factorial loadings close to 1 indicate stronger correlations (Table 8). The projection of the first two factorial loading plots indicate whether the parameters are correlated or not. If the plotted variables are close to the centre, it means that some information may be carried over to other axes. The projection of the variables on the factor plane (1 and 2) shows that first group i.e. $A, C_{d a f}, V_{m}, V R_{i}, F R$ are far from center and but close to each other. Similarly second group (GCV, M, $\mathrm{O}_{\mathrm{daf}}, \mathrm{VM}_{\mathrm{daf}}, \mathrm{VL}_{\mathrm{m}}$ and $\mathrm{VL}_{\mathrm{i}}$ ) are on the opposite side of the centre as well as to first group. These observations are replicated for each of susceptibility indices $\left(C P T, C P T_{u}, U_{v}\right.$ and $V_{\mathrm{io}_{\text {-i. }}}$ ). 
Table 5 The results of the PCCA correlation study performed between the proximate, ultimate and susceptibility indices determined for the coal samples (GCV, FR, CPT, $\left.\mathrm{CPT}_{\mathrm{u}}, \mathrm{Uv}_{\mathrm{v}}, \mathrm{HCv}_{\mathrm{v}}, \mathrm{OR}_{\mathrm{v}}, \mathrm{VR}_{\mathrm{mf}-\mathrm{m}}, \mathrm{R}_{\mathrm{im}-\mathrm{i}}\right)$.

\begin{tabular}{|c|c|c|c|c|c|c|c|c|c|c|c|c|c|c|c|c|c|c|c|}
\hline & M & Ash & $\mathbf{V M}_{\text {daf }}$ & FC & $\mathbf{C}_{\text {daf }}$ & $\mathbf{H}_{\text {daf }}$ & $\mathbf{N}_{\text {daf }}$ & $\mathbf{S}_{\text {daf }}$ & $\mathbf{O}_{\text {daf }}$ & GCV & FR & CPT & IPT & $\mathbf{C P T}_{\mathrm{u}}$ & $\mathbf{U}_{\mathbf{v}}$ & $\mathbf{H C}_{\mathbf{V}}$ & $\mathbf{O R}_{\mathbf{V}}$ & $\mathbf{V R}_{\mathrm{mo-m}}$ & $V R_{i o-i}$ \\
\hline $\mathbf{M}$ & 1.000 & & & & & & & & & & & & & & & & & & \\
\hline Ash & -0.700 & 1.000 & & & & & & & & & & & & & & & & & \\
\hline$V_{\text {daf }}$ & 0.673 & -0.840 & 1.000 & & & & & & & & & & & & & & & & \\
\hline FC & 0.334 & -0.693 & 0.193 & 1.000 & & & & & & & & & & & & & & & \\
\hline $\mathbf{C}_{\mathrm{daf}}$ & -0.526 & 0.662 & -0.728 & -0.233 & 1.000 & & & & & & & & & & & & & & \\
\hline $\mathbf{H}_{\text {daf }}$ & 0.013 & -0.205 & 0.552 & -0.350 & -0.100 & 1.000 & & & & & & & & & & & & & \\
\hline $\mathbf{N}_{\mathrm{daf}}$ & -0.499 & 0.630 & -0.699 & -0.210 & 0.916 & -0.141 & 1.000 & & & & & & & & & & & & \\
\hline$S_{\text {daf }}$ & 0.368 & -0.023 & -0.190 & 0.256 & 0.373 & -0.181 & 0.512 & 1.000 & & & & & & & & & & & \\
\hline $\mathbf{O}_{\text {daf }}$ & 0.494 & -0.636 & 0.691 & 0.236 & 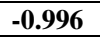 & 0.047 & -0.931 & -0.425 & 1.000 & & & & & & & & & & \\
\hline GCV & 0.711 & -0.950 & 0.776 & 0.687 & -0.657 & 0.121 & -0.567 & 0.103 & 0.628 & 1.000 & & & & & & & & & \\
\hline FR & -0.704 & 0.822 & -0.997 & -0.162 & 0.733 & -0.527 & 0.704 & 0.183 & -0.698 & $\begin{array}{l}-0.763 \\
\end{array}$ & 1.000 & & & & & & & & \\
\hline CPT & -0.570 & $\begin{array}{l}0.858 \\
\end{array}$ & -0.787 & -0.508 & 0.796 & -0.191 & 0.689 & 0.111 & -0.772 & -0.806 & 0.768 & 1.000 & & & & & & & \\
\hline IPT & -0.555 & 0.791 & -0.777 & -0.397 & 0.776 & -0.268 & $\begin{array}{l}0.601 \\
\end{array}$ & 0.038 & -0.737 & -0.792 & 0.758 & 0.958 & 1.000 & & & & & & \\
\hline $\mathbf{C P T}_{\mathrm{u}}$ & -0.479 & 0.833 & -0.636 & -0.661 & 0.590 & -0.150 & 0.546 & -0.028 & -0.567 & -0.744 & 0.598 & 0.925 & 0.847 & 1.000 & & & & & \\
\hline $\mathbf{U}_{\mathbf{V}}$ & -0.668 & 0.608 & -0.912 & 0.119 & 0.677 & -0.560 & 0.586 & 0.110 & -0.632 & -0.588 & 0.928 & 0.680 & 0.726 & 0.455 & 1.000 & & & & \\
\hline $\mathrm{HC}_{\mathrm{V}}$ & 0.289 & -0.162 & -0.047 & 0.338 & -0.165 & -0.467 & -0.214 & 0.217 & 0.184 & 0.061 & 0.034 & -0.011 & 0.150 & -0.105 & 0.156 & 1.000 & & & \\
\hline $\mathbf{O} \mathbf{R}_{\mathrm{V}}$ & 0.499 & -0.480 & 0.820 & -0.224 & -0.546 & 0.641 & -0.439 & -0.159 & 0.498 & 0.500 & -0.830 & -0.604 & -0.701 & -0.371 & -0.944 & -0.470 & 1.000 & & \\
\hline$V R_{m o-m}$ & 0.094 & -0.458 & 0.550 & 0.135 & -0.539 & 0.243 & -0.390 & -0.361 & 0.526 & 0.522 & -0.545 & -0.405 & -0.391 & -0.200 & -0.484 & -0.015 & 0.436 & 1.000 & \\
\hline$V R_{i 0-\mathrm{i}}$ & 0.366 & -0.610 & 0.795 & 0.068 & -0.634 & 0.479 & -0.643 & -0.456 & 0.622 & 0.572 & -0.804 & -0.606 & -0.539 & -0.387 & -0.746 & -0.213 & 0.722 & 0.718 & 1.000 \\
\hline
\end{tabular}


Table 6 The results of the PCCA correlation study performed between the petrographic and susceptibility parameters determined for each of the coal samples (CPT $\left.\mathrm{Uv}_{\mathrm{v}}, \mathrm{HC}_{\mathrm{v}}, \mathrm{OR}_{\mathrm{v}}, \mathrm{VR}_{\mathrm{mf}-\mathrm{m}}, \mathrm{R}_{\mathrm{im}-\mathrm{i}}\right)$.

\begin{tabular}{|c|c|c|c|c|c|c|c|c|c|c|c|c|c|c|c|c|}
\hline & $\mathbf{V L}_{\mathrm{m}}$ & $\mathbf{S F}_{\mathrm{m}}$ & $F_{m}$ & $\mathbf{V R}_{\mathrm{m}}$ & $V_{L_{i o}}$ & $\mathbf{S F}_{\text {io }}$ & $F_{\text {io }}$ & $\mathbf{V R}_{\mathrm{io}}$ & CPT & IPT & $\mathrm{CPT}_{\mathrm{u}}$ & $\mathbf{U}_{\mathbf{v}}$ & $\mathrm{HC}_{\mathrm{V}}$ & $\mathbf{O R}_{\mathrm{V}}$ & $\mathbf{V R}_{\mathrm{mo-m}}$ & $V_{R_{i-i}}$ \\
\hline $\mathbf{V L}_{\mathrm{m}}$ & 1.000 & & & & & & & & & & & & & & & \\
\hline $\mathbf{S F}_{\mathrm{m}}$ & -0.973 & 1.000 & & & & & & & & & & & & & & \\
\hline$F_{\mathrm{m}}$ & -0.707 & 0.525 & 1.000 & & & & & & & & & & & & & \\
\hline $\mathrm{VR}_{\mathrm{m}}$ & -0.598 & 0.578 & 0.433 & 1.000 & & & & & & & & & & & & \\
\hline$V_{L_{i o}}$ & 0.993 & -0.956 & -0.733 & -0.533 & 1.000 & & & & & & & & & & & \\
\hline $\mathbf{S F}_{\mathrm{io}}$ & -0.853 & 0.904 & 0.375 & 0.334 & -0.859 & 1.000 & & & & & & & & & & \\
\hline$F_{i o}$ & -0.461 & 0.306 & 0.764 & 0.385 & -0.450 & -0.036 & 1.000 & & & & & & & & & \\
\hline$V_{R_{i o}}$ & -0.725 & 0.697 & 0.538 & 0.714 & -0.679 & 0.379 & 0.648 & 1.000 & & & & & & & & \\
\hline CPT & -0.569 & 0.637 & 0.147 & 0.689 & -0.520 & 0.407 & 0.168 & 0.779 & 1.000 & & & & & & & \\
\hline IPT & -0.595 & 0.653 & 0.193 & 0.643 & -0.544 & 0.434 & 0.190 & 0.718 & 0.958 & 1.000 & & & & & & \\
\hline $\mathrm{CPT}_{\mathrm{u}}$ & -0.322 & 0.446 & -0.180 & 0.516 & -0.281 & 0.272 & -0.100 & 0.554 & 0.925 & 0.847 & 1.000 & & & & & \\
\hline $\mathbf{U}_{\mathbf{V}}$ & -0.880 & 0.847 & 0.651 & 0.662 & -0.859 & 0.589 & 0.630 & 0.804 & 0.680 & 0.726 & 0.455 & 1.000 & & & & \\
\hline $\mathrm{HC}_{\mathrm{V}}$ & -0.343 & 0.382 & 0.092 & 0.078 & -0.312 & 0.473 & -0.084 & -0.138 & -0.011 & 0.150 & -0.105 & 0.156 & 1.000 & & & \\
\hline $\mathbf{O R}_{\mathrm{V}}$ & 0.888 & -0.868 & -0.614 & -0.619 & 0.859 & -0.662 & -0.543 & -0.666 & -0.604 & -0.701 & -0.371 & -0.944 & -0.470 & 1.000 & & \\
\hline$\overline{V^{2} \text { mo-m }}$ & 0.510 & -0.447 & -0.512 & $\begin{array}{l}-0.887 \\
\end{array}$ & 0.460 & -0.284 & -0.355 & -0.562 & -0.405 & -0.391 & \begin{tabular}{|l|}
-0.200 \\
\end{tabular} & -0.484 & -0.015 & 0.436 & 1.000 & \\
\hline$V R_{\text {io-i }}$ & 0.876 & -0.858 & -0.604 & -0.816 & 0.843 & -0.708 & -0.417 & -0.775 & -0.606 & -0.539 & \begin{tabular}{|l|}
-0.387 \\
\end{tabular} & -0.746 & -0.213 & 0.722 & 0.718 & 1.000 \\
\hline
\end{tabular}

Table 7 The eigenvalues of the correlation matrix derived by the PCCA method, and the variance in correlation computed for the four spontaneous combustion susceptibility indices

\begin{tabular}{|c|c|c|c|c|c|c|c|c|c|c|c|c|}
\hline \multirow[t]{2}{*}{$\mathrm{PC}$} & \multicolumn{3}{|c|}{ CPT } & \multicolumn{3}{|c|}{ CPTu } & \multicolumn{3}{|c|}{$\mathbf{U v}$} & \multicolumn{3}{|c|}{ VRio-i } \\
\hline & Eigenvalue & $\begin{array}{l}\% \text { Total } \\
\text { variance }\end{array}$ & $\begin{array}{c}\text { Cumulative } \\
\%\end{array}$ & Eigenvalue & $\begin{array}{c}\% \text { Total } \\
\text { variance }\end{array}$ & $\begin{array}{c}\text { Cumulative } \\
\%\end{array}$ & Eigenvalue & $\begin{array}{c}\% \text { Total } \\
\text { variance }\end{array}$ & $\begin{array}{c}\text { Cumulative } \\
\%\end{array}$ & Eigenvalue & $\begin{array}{l}\% \text { Total } \\
\text { variance } \\
\end{array}$ & Cumulative $\%$ \\
\hline 1. & 8.88 & 63.42 & 63.42 & 8.61 & 61.50 & 61.50 & 8.92 & 63.75 & 63.75 & 8.84 & 63.17 & 63.17 \\
\hline 2. & 2.18 & 15.58 & 79.00 & 2.30 & 16.45 & 77.94 & 2.24 & 15.97 & 79.71 & 2.19 & 15.65 & 78.83 \\
\hline 3. & 1.22 & 8.73 & 87.72 & 1.22 & 8.72 & 86.66 & 1.21 & 8.67 & 88.39 & 1.22 & 8.73 & 87.55 \\
\hline 4. & 0.77 & 5.50 & 93.22 & 0.84 & 6.00 & 92.67 & 0.78 & 5.54 & 93.92 & 0.79 & 5.63 & 93.18 \\
\hline 5. & 0.39 & 2.75 & 95.97 & 0.45 & 3.19 & 95.86 & 0.38 & 2.71 & 96.64 & 0.48 & 3.42 & 96.60 \\
\hline 6. & 0.25 & 1.81 & 97.79 & 0.26 & 1.85 & 97.70 & 0.25 & 1.76 & 98.40 & 0.23 & 1.63 & 98.22 \\
\hline 7. & 0.15 & 1.09 & 98.87 & 0.17 & 1.25 & 98.95 & 0.15 & 1.08 & 99.49 & 0.15 & 1.06 & 99.29 \\
\hline 8. & 0.11 & 0.79 & 99.67 & 0.10 & 0.73 & 99.68 & 0.04 & 0.31 & 99.80 & 0.06 & 0.43 & 99.72 \\
\hline 9. & 0.04 & 0.26 & 99.93 & 0.03 & 0.24 & 99.93 & 0.02 & 0.18 & 99.97 & 0.04 & 0.27 & 99.99 \\
\hline 10. & 0.01 & 0.07 & 100.00 & 0.01 & 0.08 & 100.00 & 0.00 & 0.03 & 100.00 & 0.00 & 0.01 & 100.0000 \\
\hline
\end{tabular}


Table 8 The computed PCCA factor loadings of the variables in the principal component matrix for the three principal components

\begin{tabular}{|c|c|c|c|c|c|c|c|c|c|c|c|c|}
\hline \multirow[t]{2}{*}{ Variables } & \multicolumn{3}{|c|}{ CPT } & \multicolumn{3}{|c|}{ CPTu } & \multicolumn{3}{|c|}{$\mathbf{U v}$} & \multicolumn{3}{|c|}{ VRio-i } \\
\hline & PC1 & PC1 & PC1 & PC1 & $\begin{array}{l}\text { PC2 } \\
\end{array}$ & $\begin{array}{l}\text { PC3 } \\
\end{array}$ & $\begin{array}{l}\mathrm{PC} 2 \\
\end{array}$ & PC3 & $\begin{array}{l}\text { PC2 } \\
\end{array}$ & PC3 & PC2 & PC3 \\
\hline $\mathrm{M}$ & 0.706 & 0.180 & 0.343 & 0.710 & 0.160 & -0.276 & 0.711 & 0.236 & 0.317 & 0.683 & 0.286 & -0.340 \\
\hline A & -0.887 & -0.330 & -0.265 & -0.898 & -0.341 & 0.240 & -0.852 & -0.413 & -0.252 & -0.858 & -0.401 & 0.248 \\
\hline VMdaf & 0.960 & -0.184 & 0.106 & 0.961 & -0.183 & -0.104 & 0.972 & $\begin{array}{l}-0.099 \\
\end{array}$ & 0.101 & 0.965 & $\begin{array}{l}-0.100 \\
\end{array}$ & $\begin{array}{l}-0.119 \\
\end{array}$ \\
\hline Cdaf & -0.841 & -0.159 & 0.467 & -0.834 & -0.116 & -0.498 & -0.823 & -0.219 & 0.482 & -0.824 & -0.209 & -0.471 \\
\hline Hdaf & 0.365 & -0.743 & 0.204 & 0.369 & -0.695 & -0.284 & 0.415 & $\begin{array}{l}-0.704 \\
\end{array}$ & 0.231 & 0.407 & -0.712 & -0.253 \\
\hline Odaf & 0.812 & $\begin{array}{l}0.187 \\
\end{array}$ & -0.507 & 0.804 & 0.142 & 0.541 & 0.791 & 0.247 & -0.523 & 0.795 & 0.232 & 0.515 \\
\hline GCV & 0.852 & 0.376 & 0.271 & 0.860 & 0.373 & -0.230 & 0.820 & 0.457 & 0.253 & 0.824 & 0.450 & -0.246 \\
\hline FR & -0.960 & 0.202 & -0.098 & -0.961 & 0.207 & 0.090 & -0.977 & 0.115 & -0.092 & -0.968 & 0.115 & 0.111 \\
\hline VRm & -0.774 & 0.038 & 0.299 & -0.770 & 0.057 & -0.295 & -0.769 & -0.028 & 0.301 & -0.789 & 0.021 & -0.313 \\
\hline VLi & 0.784 & -0.465 & 0.250 & 0.777 & -0.482 & -0.242 & 0.825 & -0.383 & 0.248 & 0.825 & -0.395 & -0.263 \\
\hline VRi & -0.865 & 0.133 & 0.360 & -0.857 & 0.162 & -0.365 & $\begin{array}{c}-0.867 \\
\end{array}$ & 0.071 & 0.364 & $\begin{array}{c}-0.869 \\
\end{array}$ & 0.087 & -0.350 \\
\hline CPT & -0.883 & -0.259 & 0.085 & -0.723 & -0.457 & 0.090 & $\begin{array}{c}-0.908 \\
\end{array}$ & 0.336 & 0.002 & 0.865 & -0.282 & 0.090 \\
\hline CPTu & 0.706 & 0.180 & 0.343 & 0.710 & 0.160 & -0.276 & 0.711 & 0.236 & 0.317 & 0.683 & 0.286 & -0.340 \\
\hline Uv & -0.887 & -0.330 & -0.265 & -0.898 & -0.341 & 0.240 & -0.852 & -0.413 & -0.252 & -0.858 & -0.401 & 0.248 \\
\hline VRio-i & 0.960 & -0.184 & 0.106 & 0.961 & $\begin{array}{l}-0.183 \\
\end{array}$ & -0.104 & 0.972 & $\begin{array}{l}-0.099 \\
\end{array}$ & 0.101 & 0.965 & $\begin{array}{l}-0.100 \\
\end{array}$ & $\begin{array}{c}-0.119 \\
\end{array}$ \\
\hline
\end{tabular}


An analysis of a plot of the weighted parameter will indicate a significant correlation where these parameters are spatially grouped together. As first group are on opposite sides of the second group so, they are negatively correlated. However, variables like fixed carbon and $\mathrm{H}_{\text {daf }}$ are orthogonal to variable CPT, $\mathrm{CPT}_{\mathrm{u}}, \mathrm{U}_{\mathrm{v}}$ and $\mathrm{VR}_{\mathrm{io}-\mathrm{I}}$, which signifies a zero correlation. The projections of the cases (for samples) on the factor plane (1x2) are shown in Fig. 8. Fig. 8 shows that all samples are classified into four clusters where first cluster $(\mathrm{X}, \mathrm{Y})$ having samples 1, 2 \& 4; second cluster (X, -Y) having sample 3; third cluster (-X, Y) having samples 7, 8, 9 \&10, and fourth cluster $(-\mathrm{X},-\mathrm{Y})$ having samples $5,6, \& 11$. All four clusters may divided into three categories as per their susceptibility towards spontaneous tendency i.e. low (first cluster: samples 1, 2 \&4), medium (second and third cluster: samples 3, 7, 8, 9 \& 10) and high (fourth cluster: samples 5, 6 \&11).

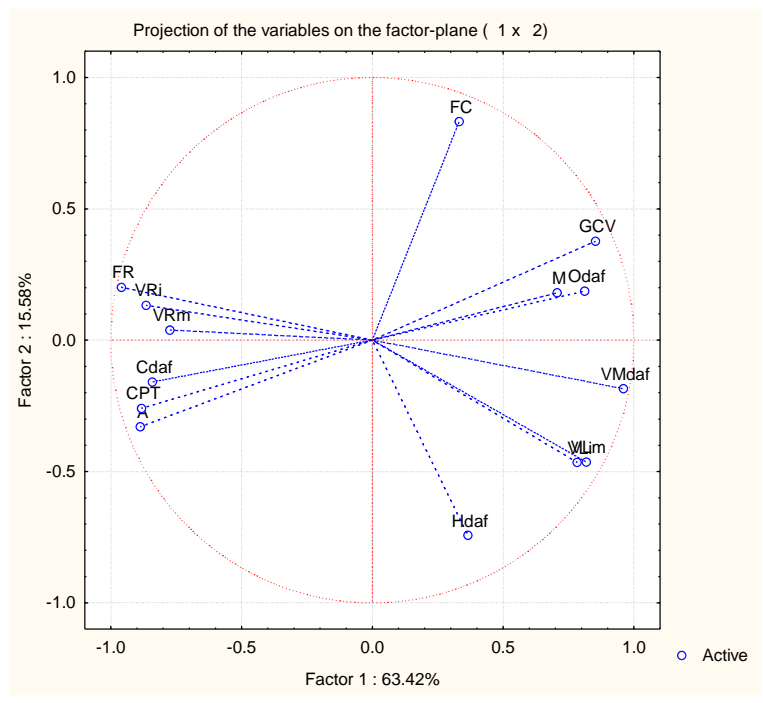

(a) CPT with all thirteen basic coal characteristics

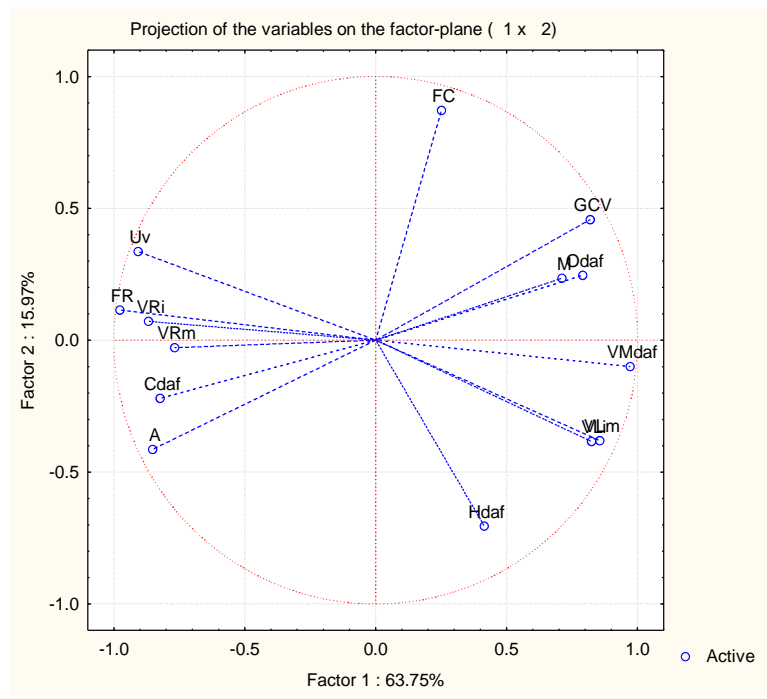

(c) $U_{v}$ with all thirteen basic coal characteristics

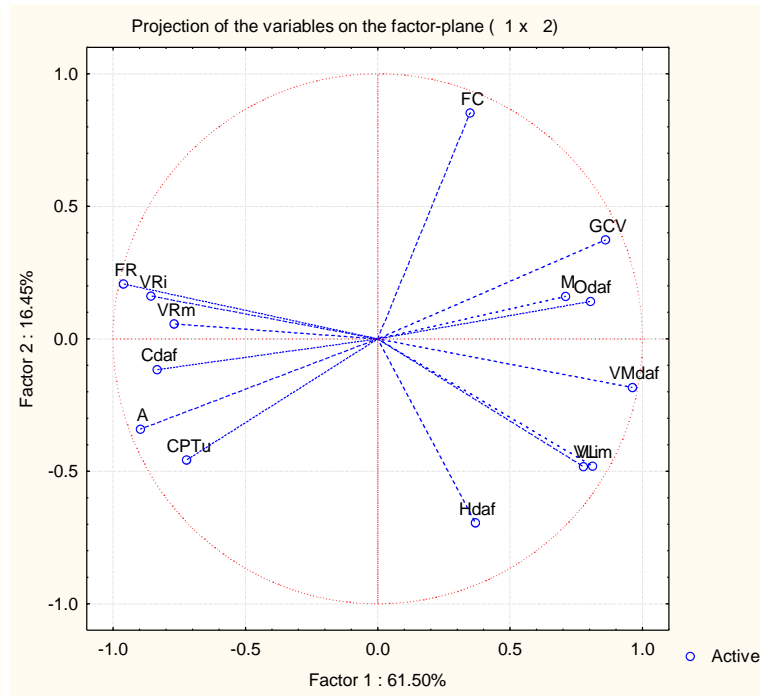

(b) $\mathrm{CPT}_{\mathrm{u}}$ with all thirteen basic coal characteristics

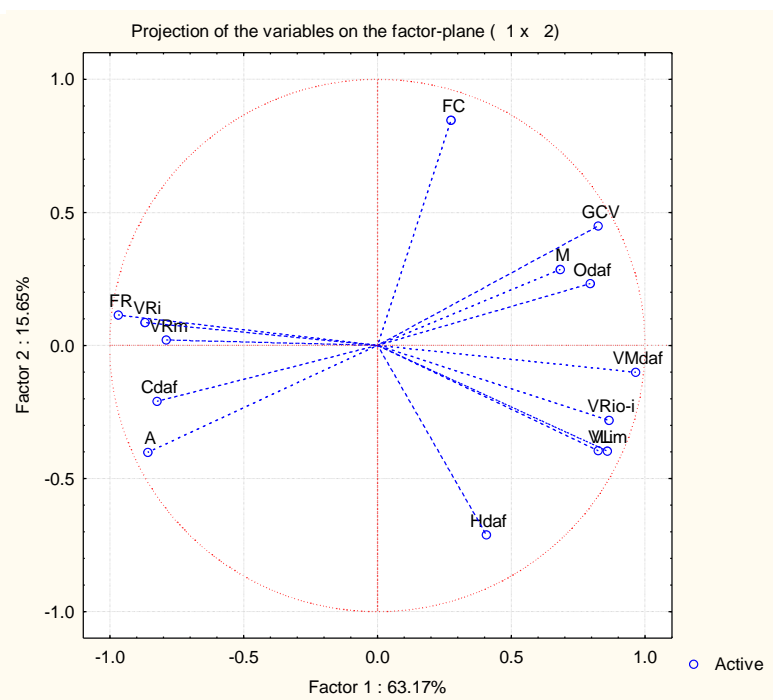

(d) $\mathrm{VR}_{\text {io-i }}$ with all thirteen basic coal characteristics

Fig. 6. Projection of variables on the factor plane. 


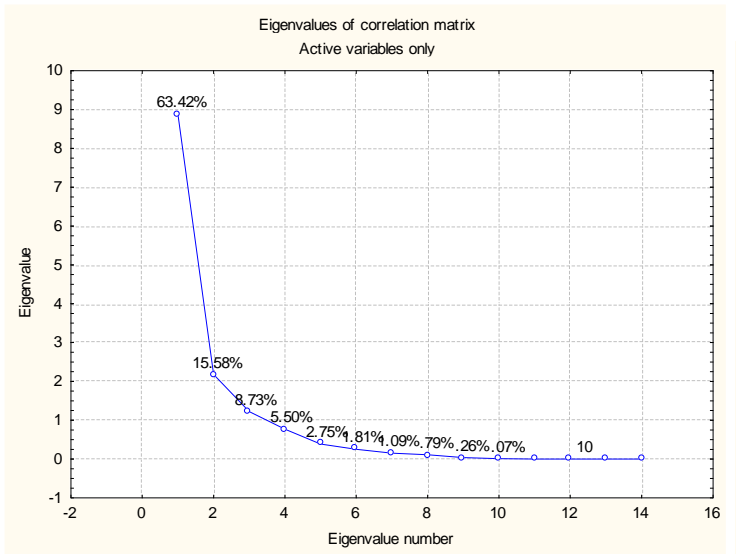

(a) CPT with all thirteen basic coal characteristics

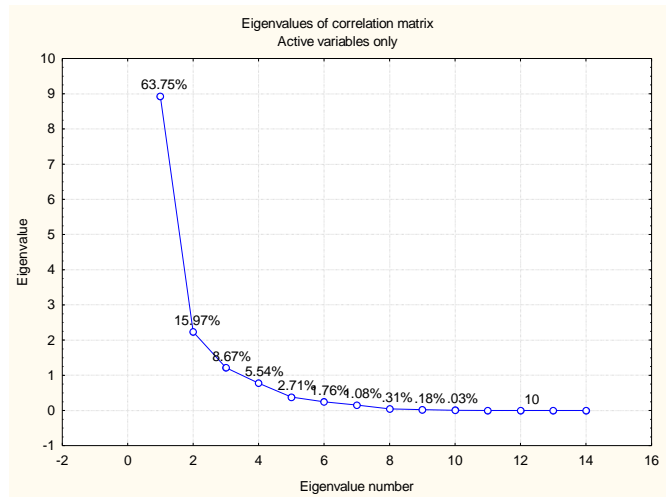

(c) $U_{v}$ with all thirteen basic coal characteristics

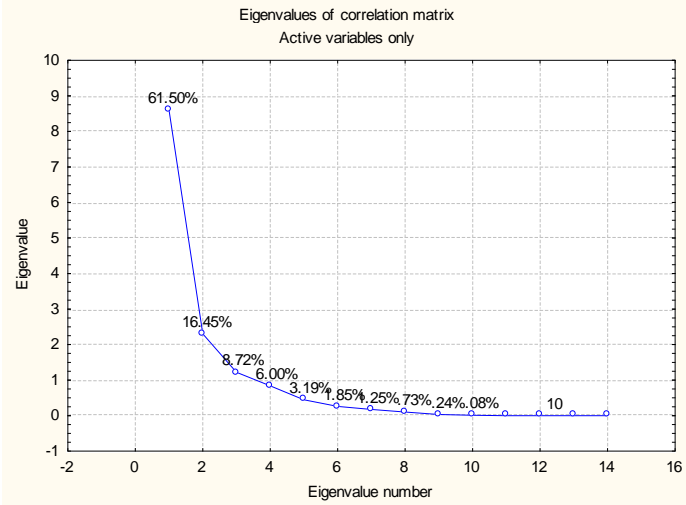

(b) $\mathrm{CPT}_{\mathrm{u}}$ with all thirteen basic coal characteristics

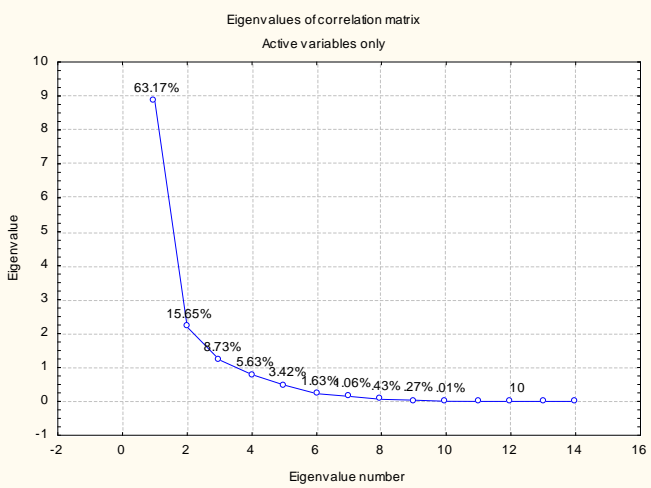

(d) $\mathrm{VR}_{\text {io-i }}$ with all thirteen basic coal characteristics

Fig. 7. Scree plot to find the factorial loadings 

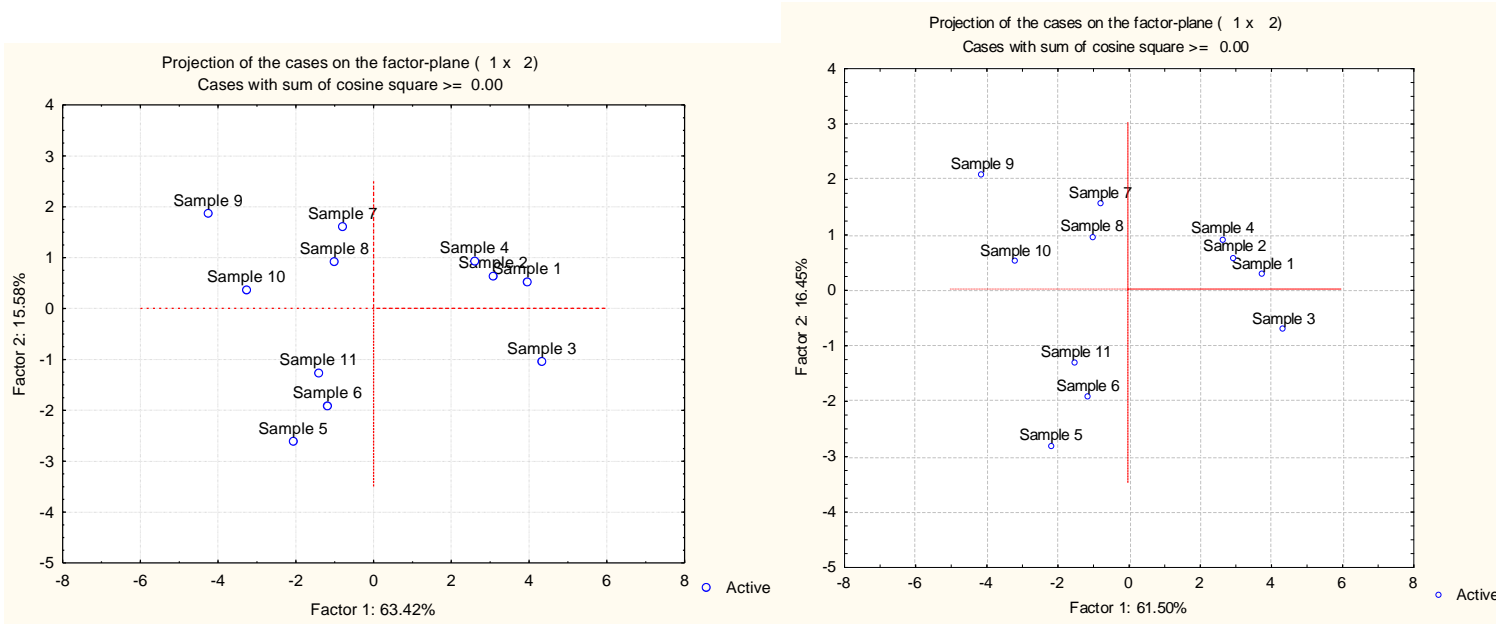

a) CPT with all thirteen basic coal characteristics (b) $\mathrm{CPT}_{\mathrm{u}}$ with all thirteen basic coal characteristics
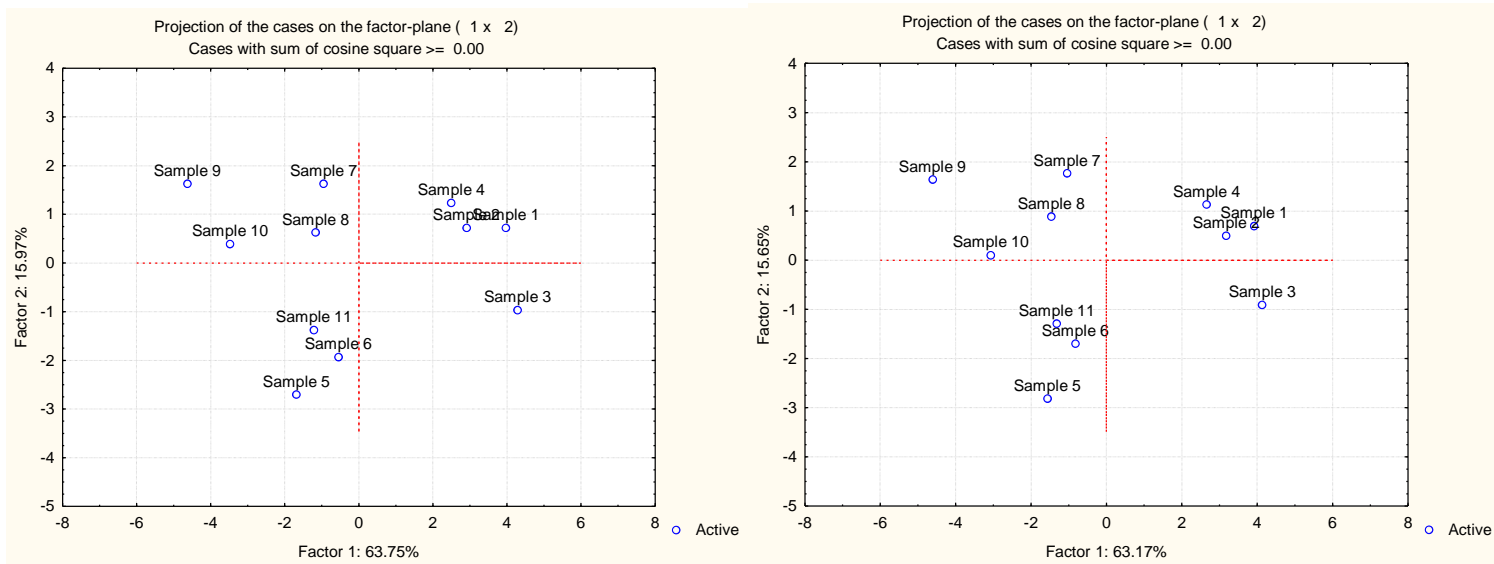

(c) $U_{v}$ with all thirteen basic coal characteristics (d) $V_{R}$ io-i with all thirteen basic coal characteristics

Fig. 8. Projections of the cases (samples) on the factor plane (1x2)

\subsubsection{Fixed Nonlinear Regression Models (FNRM)}

The general purpose of multiple regression is to learn more about the relationship between several independent variables and a dependent variable. In multiple regression, the regression coefficient $\mathrm{R}$ can assume a value between 0 and 1 . This study employs the following set of standard functions (including: $X^{2}, X^{3}, X^{4}, X^{5}, \sqrt{ }$, $L n X$, $\log X$ and $1 / X)$ to specify nonlinear transformations. The above determined physical and chemical characteristics of the coal samples including the proximate, ultimate analysis and petrographic analyses data sets were considered as the independent parameters and the susceptibility indices CPT, CPT $\mathrm{u}, \mathrm{U}_{\mathrm{v}}$ and $\mathrm{VR}_{\mathrm{io}-\mathrm{i}}$ were taken as dependent parameters, where the dependence of these variables were considered sequentially. The fitness of each model equation is determined by an analysis of the computed regression coefficients, level of significance and standard error. Accordingly, twelve model equations were tested for each of the susceptibility indices. A summary of the fitness of each of these models to each of the susceptibility indices in terms of the computed R-Squared, Adjusted R-squared and standard error of mean are presented on Table 9. 'R-Squared' value of these model equations obtained from non-linear regression analysis ranges from 0.3194 to 0.9558 , and the standard error mean (SEM) ranges from 0.0840 to 9.3291 . To develop each model equation it has been observed that model was significant in the range 0.00004 to 0.2117 . Figs. 9 (a) to (1) present a comparative nonlinear plot of the predicted and observed 
values for the four susceptibility indices. It may be observed from Table 9 that the model equation developed for the four different susceptible indices gives the highest level of significance and fixed nonlinear regression analysis indicates maximum 'R-Squared' value of 0.6855 with proximate analysis. Therefore by using multiple fixed nonlinear regression analysis of the experimental data it may be concluded that the susceptibility index i.e. unaltered vitrinite $\left(\mathrm{U}_{\mathrm{v}}\right)$ may be used to categorize/classify the coal seam. It also correlates with other standard methods like CPT and $\mathrm{CPT}_{\mathrm{u}}$. Similarly, the results suggest that the $\mathrm{VR}_{\mathrm{io}-\mathrm{i}}$ method should be explored further by employing a larger number of coals to assess the propensity spontaneous combustion of coal.

Table 9 Measure of fit of experimental data to fixed multiple nonlinear regression models

\begin{tabular}{|c|c|c|c|c|c|}
\hline $\begin{array}{l}\text { S1. } \\
\text { No. }\end{array}$ & Equation & $\mathrm{R}^{2}$ & $\begin{array}{l}\text { Adjusted } \\
\mathrm{R}^{2}\end{array}$ & P level & $\begin{array}{l}\text { Standard error } \\
\text { of estimate }\end{array}$ \\
\hline \multirow[t]{5}{*}{1} & Proximate Analysis $\left(\mathrm{M}, \mathrm{A}, \mathrm{VM}_{\mathrm{daf}}\right)$ & & & & \\
\hline & $C P T=110.286+\frac{0.492}{M}+14.486 \sqrt{A}$ & 0.7575 & 0.6535 & 0.0147 & 6.9908 \\
\hline & $\mathrm{CPT}_{u}=115.079-\frac{2.147}{\mathrm{M}}+84.854 \log A$ & 0.7283 & 0.6119 & 0.0215 & 6.2819 \\
\hline & $U_{v}=-137.33+\frac{5.755}{M}-60.722 \sqrt{A}+\frac{6290.638}{V M_{d a f}}$ & 0.9558 & 0.9369 & 0.00004 & 3.5580 \\
\hline & $V R_{\text {io-i }}=-1.791-0.180 M+0.002 A+0.072 V M_{d a f}$ & 0.6855 & 0.5507 & 0.0352 & 0.1102 \\
\hline \multirow[t]{5}{*}{2} & Ultimate Analysis and GCV $\left(\mathrm{C}_{\mathrm{daf}}, \mathrm{O}_{\mathrm{daf}}, \mathrm{GCV}\right)$ & & & & \\
\hline & $C P T=-540.402+8.506 C_{d a f}+5.523 O_{d a f}-0.077 G C V$ & 0.7832 & 0.6904 & 0.0100 & 6.6088 \\
\hline & $\mathrm{CPT}_{u}==551.385-0.033 C_{d a f}^{2}+\frac{690.237}{O_{d a f}}-6.34 G C V$ & 0.6369 & 0.4814 & 0.0567 & 7.2620 \\
\hline & $U_{v}=-3285.07+36.43 C_{d a f}+29.86 O_{d a f}$ & 0.6965 & 0.5664 & 0.0313 & 9.3291 \\
\hline & $V R_{i o-i}=4.004-0.049 C_{d a f}-0.017 O_{d a f}$ & 0.4539 & 0.2199 & 0.2117 & 0.1453 \\
\hline \multirow[t]{5}{*}{3} & Vitrinite Reflectance & & & & \\
\hline & $C P T=111.518+61.355 V R_{i}$ & 0.6244 & 0.5305 & 0.0199 & 8.1381 \\
\hline & $\mathrm{CPT}_{u}==190.611+35.359 V R_{i}$ & 0.3194 & 0.1493 & 0.2144 & 9.3007 \\
\hline & $\mathrm{U}_{v}==15.927+40.154 V R_{i}$ & 0.8412 & 0.8016 & 0.0006 & 6.3107 \\
\hline & $\mathrm{VR}_{i o-i}==0.107-0.458 V R_{i}$ & 0.7913 & 0.7391 & 0.0019 & 0.0840 \\
\hline
\end{tabular}



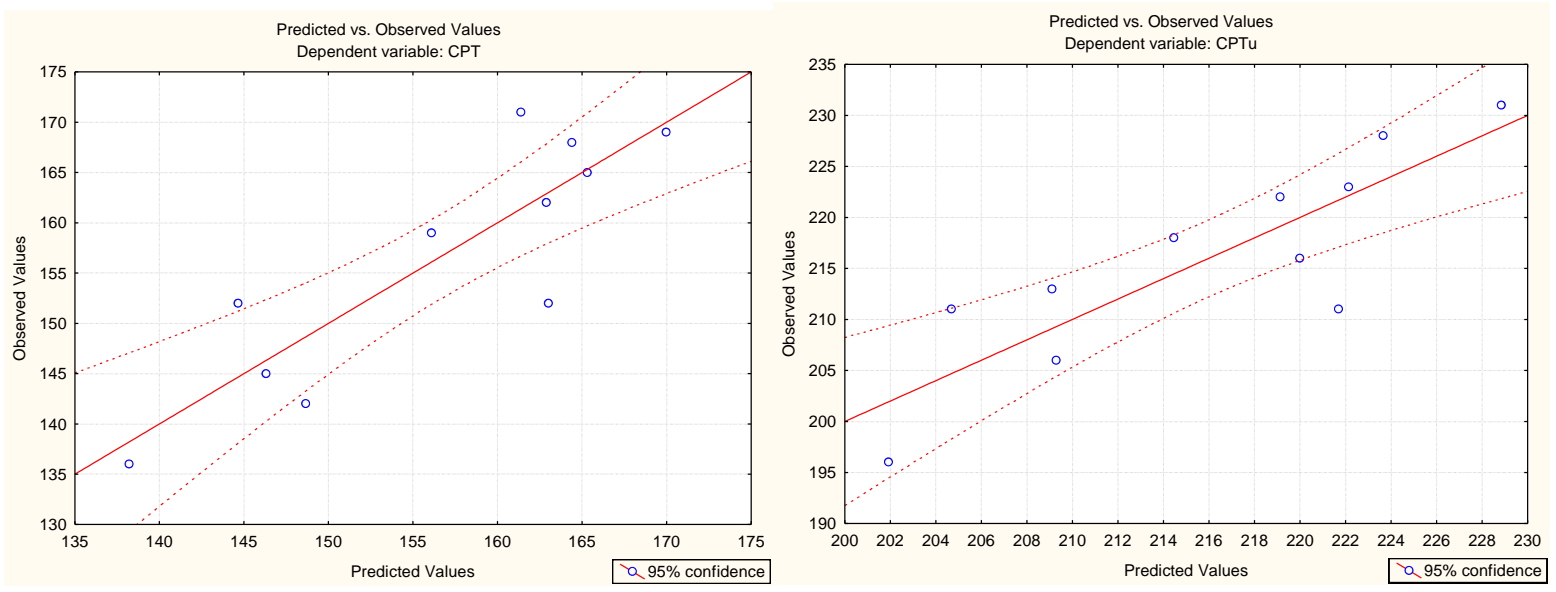

(a) CPT with Proximate Analysis (M, A, VM $\mathrm{VMaf}_{\text {da }}$

(b)

CPTu with Proximate Analysis (M, A, $\mathrm{VM}_{\text {daf }}$ )
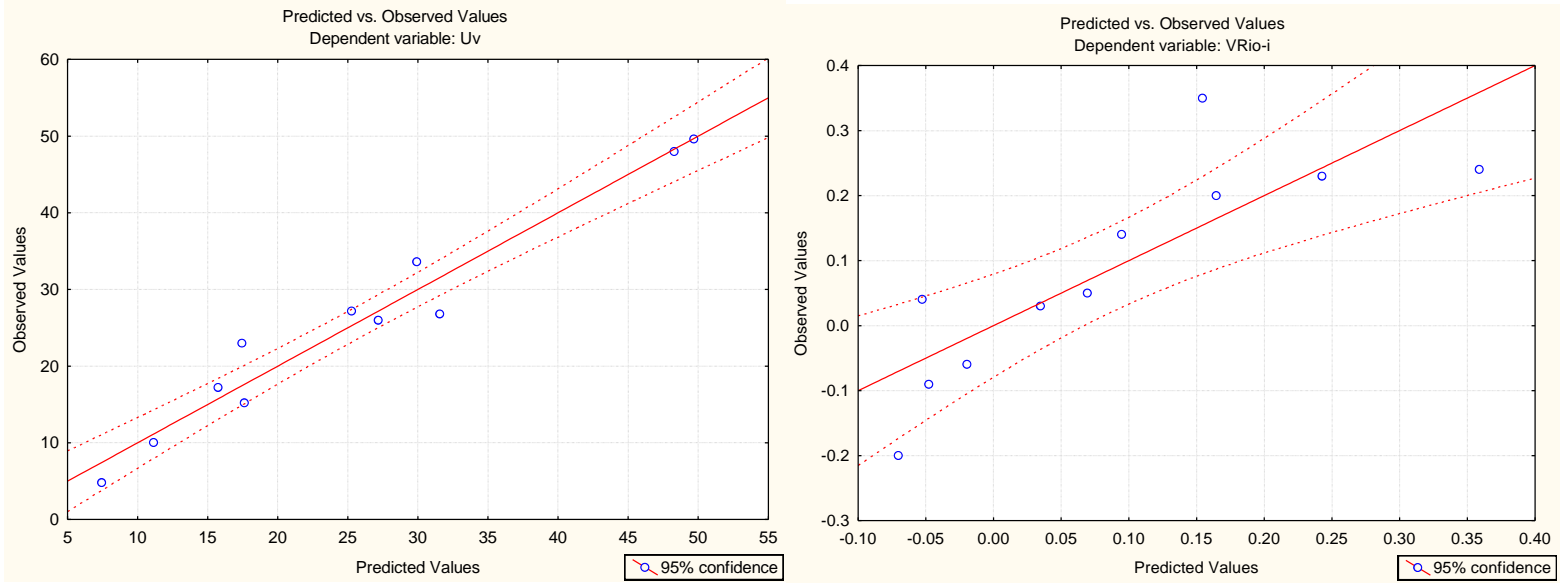

(c) CPT with Proximate Analysis $\left(\mathrm{M}, \mathrm{A}, \mathrm{VM}_{\mathrm{daf}}\right)$

(d) VRio-i with Proximate Analysis (M, A, $\left.\mathrm{VM}_{\text {daf }}\right)$
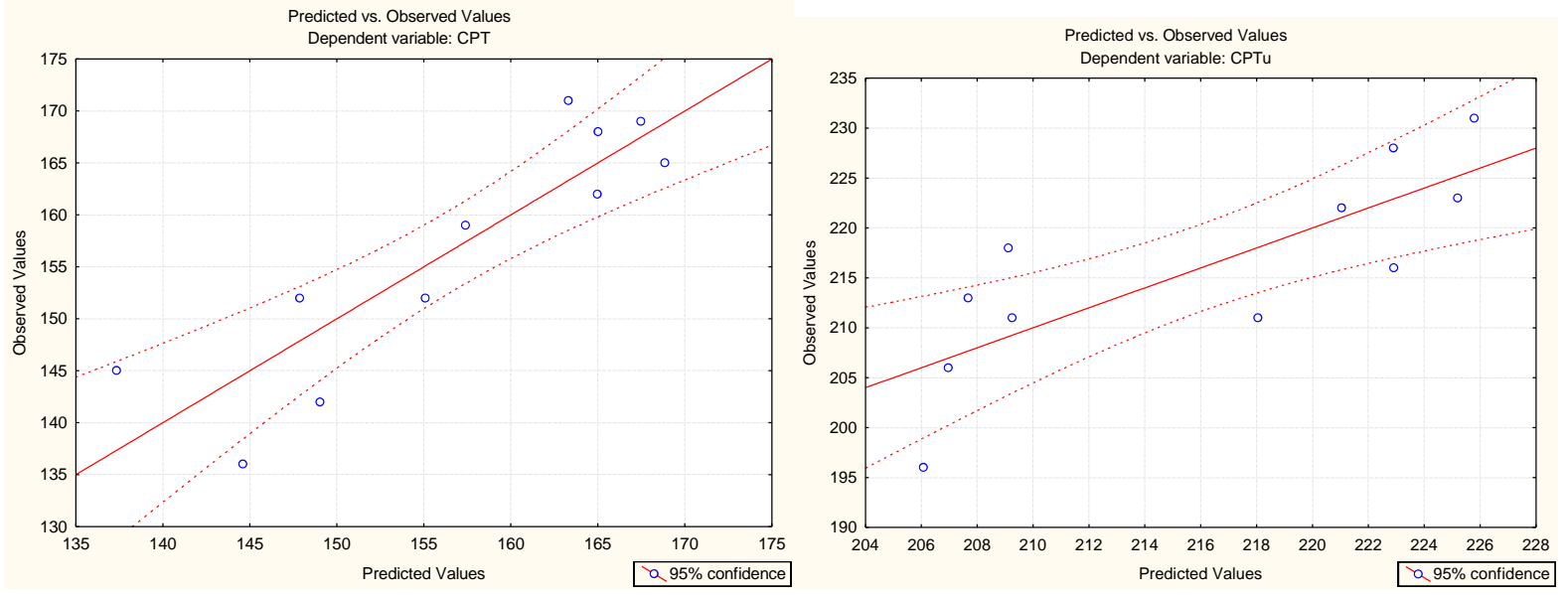

(e) CPT with Ultimate Analysis and GCV $\left(\mathrm{C}_{\mathrm{daf}}, \mathrm{O}_{\mathrm{daf}}, \mathrm{GCV}\right)$ (f)

CPTu with Ultimate Analysis and GCV $\left(\mathrm{C}_{\mathrm{daf}}, \mathrm{O}_{\mathrm{daf}}, \mathrm{GCV}\right)$ 


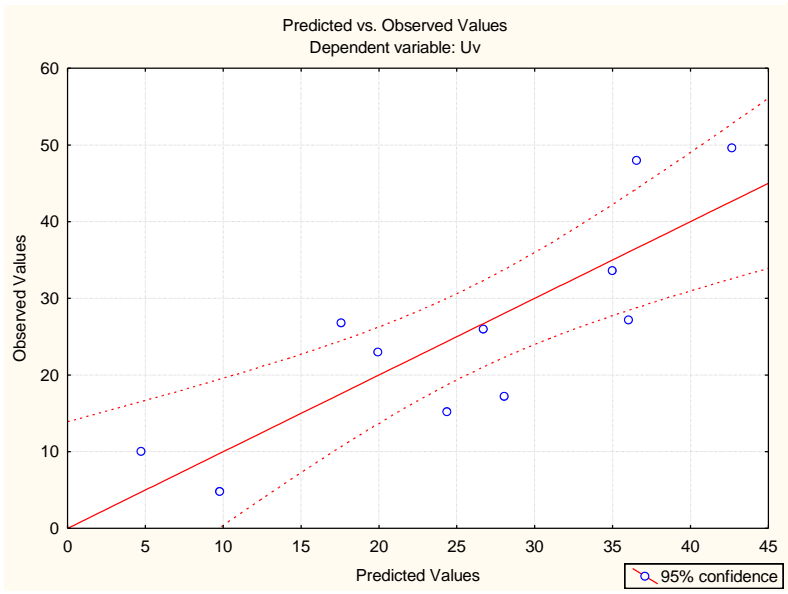

(g) Uv with Ultimate Analysis and GCV ( $\left.\mathrm{C}_{\text {daf }}, \mathrm{O}_{\text {daf }}, \mathrm{GCV}\right)$

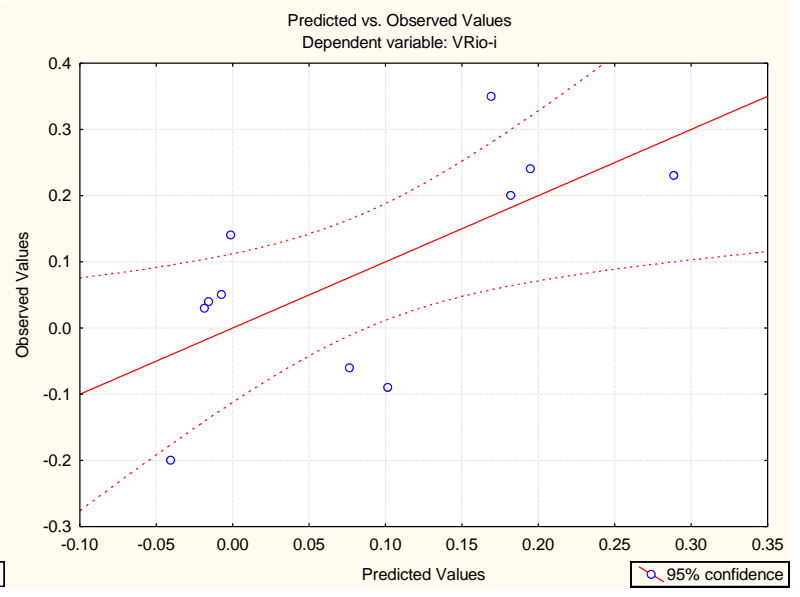

(h) VRio-i with Ultimate Analysis and GCV ( $\left.\mathrm{C}_{\mathrm{daf}}, \mathrm{O}_{\mathrm{daf}}, \mathrm{GCV}\right)$

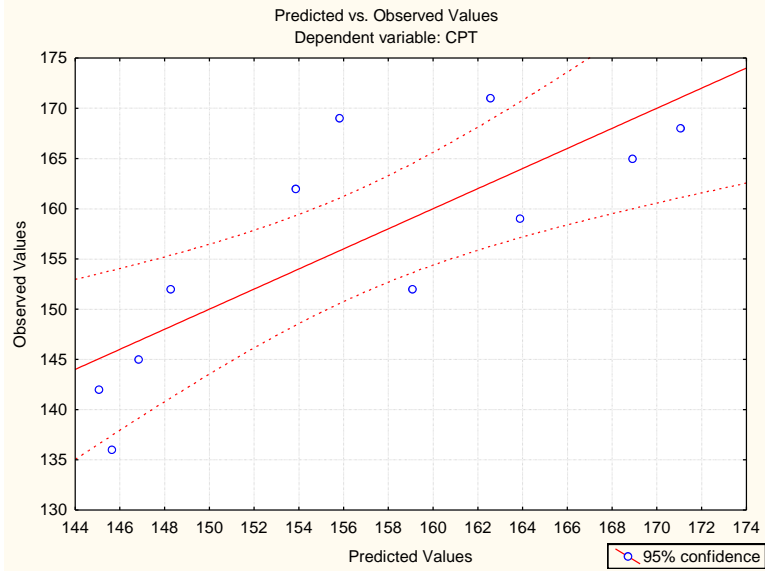

(i) CPT with Vitrinite Reflectance

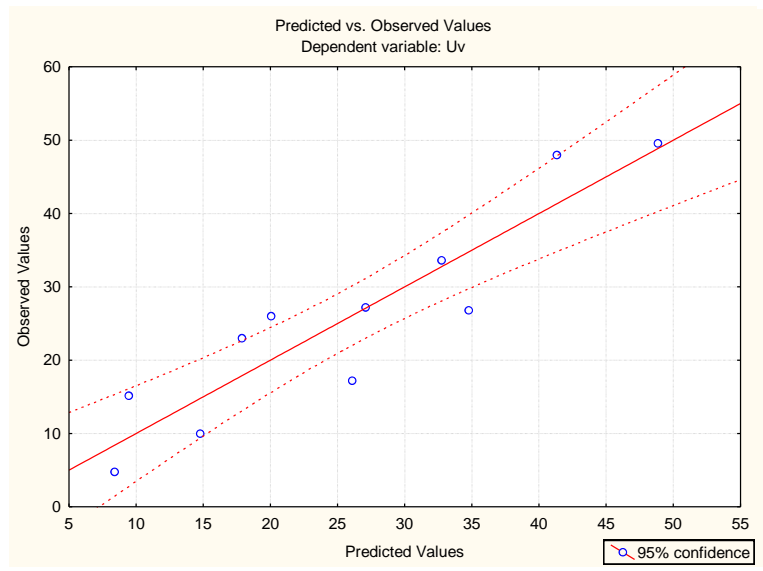

(K) Uv with Vitrinite Reflectance

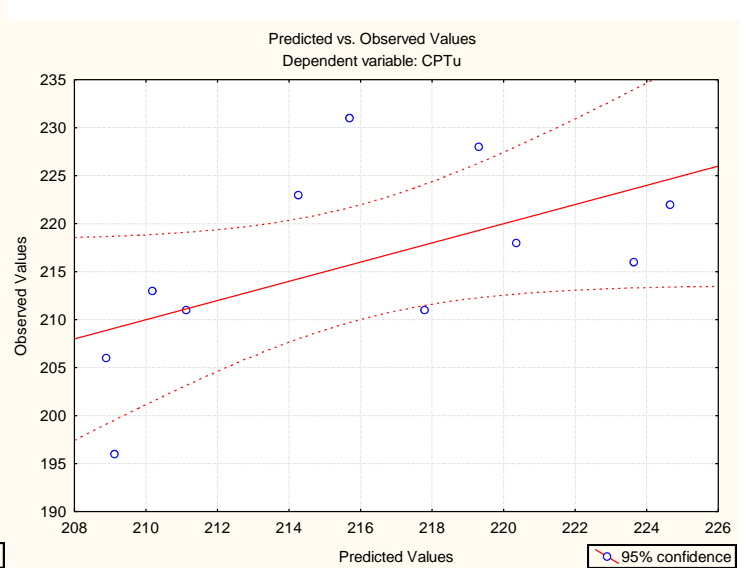

(j)

CPTu with Vitrinite Reflectance

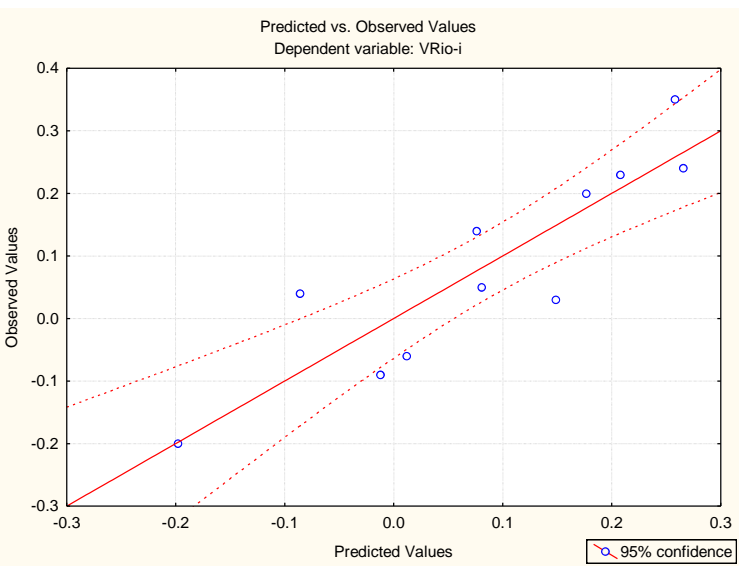

(L) VRio-i with Vitrinite Reflectance

Fig. 9. Fixed multiple non-linear comparative plot of actual to predicted data 


\subsection{CONCLUSIONS}

The study has presented the results of a series of analytical investigations to characterise the characteristic properties (proximate, ultimate, GCV), petrography (macerals, rank of fresh coal; morphology and rank of oxidised coal), and spontaneous combustion susceptibility indices (CPT and $\mathrm{CPT}_{\mathrm{u}}$ ) for eleven coal samples from a number of mines across the Jaharia Coalfield, Northeast India. Subsequent cross correlation studies suggest potential relationships between coal characteristics properties with the changes in morphology observed in laboratory heat treated coal samples, and the liability of such coals to spontaneously combust. This new method requires minimal equipment or preparation of the coal samples. A TGA could even potentially be used to generate these samples individually for block preparation and petrographic analysis. Of the eleven coal samples examined in this study samples 1,2,3 and 4 exhibit properties that confirm the susceptibility of the coals to spontaneously heating and this agrees with known behaviour from the mine sites themselves. The one exception was in the analyses of sample number 5 (Table1) collected from the Enna surface coal mine, where local geotechnical conditions and the presence of old near surface workings significantly influence the onset of spontaneous heating. It was also concluded that coal samples collected from the same coal seam but at different depths behave similarly under laboratory conditions, and the liability of a coal to spontaneous combustion is not dependent upon the depth of the coal sample within the coal seam. The eleven coal samples studied were divided into three categories as per their susceptibility to self-heating i.e. low (first cluster: coal samples 1, $2 \& 4$ ), medium (second and third cluster: coal samples 3, 7, 8, $9 \& 10$ ) and high (fourth cluster: coal samples 5, 6 \&11).

It is concluded that the proposed morphology study $\left(U_{v}\right)$ delivers an alternative measure of the liability of a coal to spontaneous combustion as compared to two crossing point temperature methods (including CPT and $\mathrm{CPT}_{\mathrm{u}}$ ). A positive change in reflectance $\left(\mathrm{V}_{\mathrm{io-i}}\right)$ of a coal sample pre and post heating in the muffle furnace described above, recommends that further studies be performed to classify the susceptibility of the coal to spontaneous combustion.

A chemo metric analysis of the intrinsic properties of the coal samples i.e. moisture, ash, volatile matter, carbon and oxygen on daf basis confirms that these parameters exhibit a positive correlation to the spontaneous combustion susceptibility indices whereas hydrogen, fixed carbon, vitrinite, inertinite and liptinite have no correlation with susceptibility indices. Principal component and classification analysis concludes that $\mathrm{U}_{\mathrm{v}}$ gives a better indicator for study of spontaneous combustion of coal as compared to CPT and $\mathrm{CPT}_{\mathrm{u}}$ which further corroborates the experiments. Fixed multiple nonlinear regression analysis verifies the same.

\section{Acknowledgement}

Authors are grateful to Commonwealth Scholarship Commission, UK and University of Nottingham for their financial support (Commonwealth Scholarship and Fellowship Plan -2010, INCS-2010-192). The authors are obliged to Ministry of Human Resources and Development, Government of India and Council of Scientific and Industrial Research (CSIR) for their kind permission to avail the above fellowship. Authors acknowledge thanks to all staffs of Mine Fire, Ventilation and Miner's Safety Research Group, CSIR-CIMFR for necessary help for sample collection. 


\section{REFERENCES}

1. Mohalik, N.K., A study of the spontaneous heating of Indian coals. Ph.D. Thesis The University of Nottingham, 2013.

2. Banerjee, S.C., Prevention and combating mine fires. Oxford and IBH Publishing Co. Pvt. Ltd., 2000: p. 33.

3. Mohalik, N.K., A study of spontneous heating of Indian coals. PhD Thesis, Faculty of Engineering, University of Nottingham, UK, 2013.

4. Morris, R. and T. Atkinson, Seam factor and the spontaneous heating of coal. Mining Science and Technology, 1988. 7(2): p. 149-159.

5. Chandra, D., et al., An appraisal of spontaneous combustion of Ib - Valley coals of Orissa. Minetech, 1991. 12(3): p. 39-44.

6. Chandra, D. and Y.V.S. Prasad, Effect of coalification on spontaneous combustion of coals. International Journal of Coal Geology, 1990. 16(1-3): p. 225-229.

7. Benfell, K.E., B.B. Beamish, and K.A. Rodgers, Effect of resinite on the combustion of New Zealand subbituminous coal. Thermochimica Acta, 1997. 298(1-2): p. 119-122.

8. Misra, B.K. and B.D. Singh, Susceptibility to spontaneous combustion of Indian coals and lignites. An organic petrography autopsy. International Journal of Coal Geology, 1994. 25: p. 265-286.

9. Avila, C.R., Predicting self-oxidation of coals and coal/biomass blends using thermal and optical methods. $\mathrm{PhD}$ thesis, University of Nottingham., 2012.

10. Kruszewska, K.J., B.C.J. Labuschagne, and V.M. du Cann, Relating coal oxidation and hydrophobicity: a petrographic approach. Fuel, 1996. 75(14): p. 1611-1616.

11. Kruszewska, K.J. and V.M. du Cann, Detection of the incipient oxidation of coal by petrographic techniques. Fuel, 1996. 75(6): p. 769-774.

12. Pattanaik, D., P. Behera, and B. Singh, Spontaneous Combustibility Characterisation of the Chirimiri Coals, Koriya District, Chhatisgarh, India. International Journal of Geosciences, 2011. 2 (3): p. 336-347.

13. Ogunsola, O.I. and R.J. Mikula, A study of spontaneous combustion characteristics of Nigerian coals. Fuel 1990. 70: p. 258-261.

14. Ingram, G.R. and J.D. Rimstidt, Natural weathering of coal. Fuel, 1984. 63 p. 292-296.

15. Ivanova, A.V. and L.B. Zaitseva, Influence of oxidability of carboniferous coals from the Dobrudja foredeep on vitrinite reflectance. Lithology and Mineral Resources, 2006. 41(5): p. 435-439.

16. Chandra, D., Reflectance of oxidized coals. Economic Geology, 1958. 53(1): p. 102-108.

17. Chandra, D., Reflectance and microstructure of weathered coals. Fuel, 1962. 41: p. 185-193.

18. Marchioni, D.L., The detection of weathering in coal by petrographic, rheologic and chemical methods. International Journal of Coal Geology, 1983. 2(3): p. 231-259.

19. Calemma, V., et al., Changes in optical properties of coals during air oxidation at moderate temperature. Fuel, 1995. 74(3): p. 383-388.

20. Gray, R.J., A.H. Rhoades, and D.T. King, Detection of oxidized coal and the effect of oxidation on the technological properties. Trans Soc Min Eng AIME, 1976. 260(4): p. 334-341. 
21. Nandi, B.N., L.A. Ciavaglia, and D.S. Montgomery, The variation of the microhardness and reflectance of coal under conditions of oxidation simulating weathering. Journal of Microscopy, 1977 109 (1): p. 93-103.

22. Pearson, D.E. and S. Creaney, Reflectance of carbonized vitrinites as a measure of oxidation of a coking coal. Fuel, 1981. 60(3): p. 273-275.

23. Benedict, L.G. and W.E. Berry, Recognition and measurement of coal oxidation. Bituminous Coal Research Report, Monroeville, Pennstate, 1964: p. 41.

24. Chandra, D., Reflectance of Indian Coals. Quarterly Journal of Geolgical Mining and Metallurgy Society, India 1965. 37(37): p. 37.

25. Chandra, D., Fundamentals of coal petrology - oxidized coal. E. Stach, M.Th. Mackowsky, M. Teichmüller, R. Teichmüller, G.H. Taylor, D. Chandra (Eds.), Stach's Textbook of Coal PetrologyGebrüder-Borntraeger, Berlin-Stuttgart 1975: p. 159-164.

26. Stach, E., et al., Stach's Textbook of Coal Petrology. 1982. Gebrüder Borntraeger, Berlin p. 535

27. Crelling, J.C., R.H. Schader, and L.G. Benedict, Effects of weathered coal on coking properties and coke quality. Fuel 1979. 58: p. 542-546.

28. Lowenhaupt, D.E. and R.J. Gray, The alkali-extraction test as a reliable method of detecting oxidized metallurgical coal. International Journal of Coal Geology, 1980. 1(1): p. 63-73.

29. Ndaji, F.E. and K.M. Thomas, The effect of oxidation on the macromolecular structure of coals. Fuel, 1995. 74: p. 932-937.

30. Chen-Brauchler, D., et al., Estimation of near subsurface coal fire gas emissions based on geophysical investigations. American Geophysical Union, Fall Meeting 2009, 2009.

31. Peters, W.C., Exploration and mining geology. 1978: p. 416-425.

32. IS-436-Part-1/Sec-1, Methods for sampling of coal and coke: Part 1 Sampling of coal, Sec 1 Manual sampling (first revision) (Amendment 1). Bureau of Indian Standards, New Delhi, 1964: p. 3-23.

33. Paul, S. and R. Chatterjee, Mapping of cleats and fractures as an indicator of in-situ stress orientation, Jharia coalfield, India. International Journal of Coal Geology, 2011. 88(2-3): p. 113-122.

34. DGMS Cir.Tech.3/1975, Determination of crossing point and ignition point temperature of coal seams for assessing their proneness to spontaneous heating. 1975.

35. Avila, C., T. Wu, and E. Lester, Petrographic characterization of coals as a tool to detect spontaneous combustion potential. Fuel, 2014. 125(0): p. 173-182.

36. BS-ISO-7404-3, Methods for the petrographic analysis of coals - method of determining maceral group composition British standards institute, 2009.

37. BS-6127-5, Petrographic analysis of bituminous coal and anthracite - Part 5:method of determining microscopically the reflectance of vitrinite. British standards institute, 1995.

38. Lester, E., et al., An automated image analysis system for major maceral group analysis in coals. Fuel, 1994. 73(11): p. 1729-1734.

39. Cloke, M., et al., Automated maceral analysis using fluorescence microscopy and image analysis. Fuel, 1995. 74(5): p. 659-669.

40. Cloke, M. and E. Lester, Characterization of coals for combustion using petrographic analysis: a review. Fuel, 1994. 73(3): p. 315-320. 
41. Arisoy, A. and B. Beamish, Mutual effects of pyrite and moisture on coal self-heating rates and reaction rate data for pyrite oxidation. Fuel, 2015. 139: p. 107-114.

42. Deng, J., et al., Effects of pyrite on the spontaneous combustion of coal. International Journal of Coal Science \& Technology, 2015. 2(4): p. 306-311.

43. Ribeiro, J., et al., Petrography and mineralogy of self-burning coal wastes from anthracite mining in the El Bierzo Coalfield (NW Spain). International Journal of Coal Geology, 2016. 154: p. 92-106.

44. Kus, J., M. Misz-Kennan, and Iccp, Coal weathering and laboratory (artificial) coal oxidation. International Journal of Coal Geology, 2017. 171: p. 12-36.

45. Misz-Kennan, M. and M.J. Fabiańska, Application of organic petrology and geochemistry to coal waste studies. International Journal of Coal Geology, 2011. 88(1): p. 1-23.

46. Misz-Kennan, M. and M. Fabianska, Thermal transformation of organic matter in coal waste from Rymer Cones (Upper Silesian Coal Basin, Poland). International Journal of Coal Geology, 2010. 81(4): p. 343-358.

47. Chapter 14 - Thermal Transformations of Waste Rock at the Starzykowiec Coal Waste Dump, Poland A2 Stracher, Glenn B, in Coal and Peat Fires: A Global Perspective, A. Prakash and E.V. Sokol, Editors. 2015, Elsevier: Boston. p. 387-429.

48. Misz, M., M. Fabiańska, and S. Ćmiel, Organic components in thermally altered coal waste: Preliminary petrographic and geochemical investigations. International Journal of Coal Geology, 2007. 71(4): p. 405424.

49. Rencher, A.C., Methods of Multivariate Analysis. A JOHN WILEY \& SONS, INC. PUBLICATION, 2002.

50. STATISTICA-7.0, Electronic mannual statistica 7. 2004. 